封建社會をめぐる諧問題

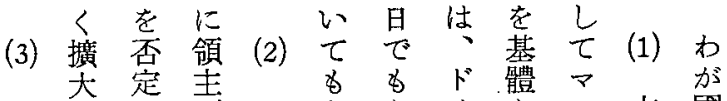
特すし制いななイとと古國 殊る、のわ找扔ツするク典に 經傾こ發ゆ通ほにる共學招

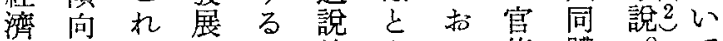

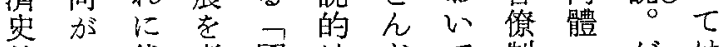
的あ代考國地

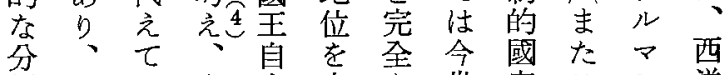

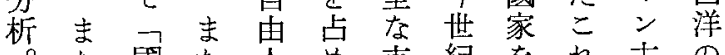
。た國た人め变紀を机古の 全王氏 學て 配 の考主代封 體自自族說道心的三主閣に建 亡 由 由 制 。る 地 - そ連つ 社 乙攵人の心㫼

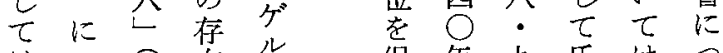
はつ肉在文保年九林つ

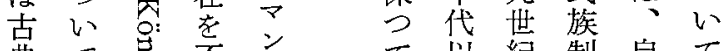
典て 劳否古紀制自て

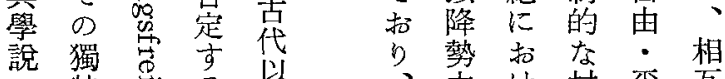

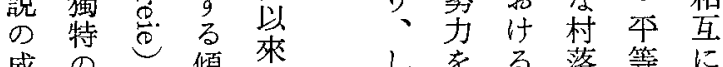
成 $\omega し$ 傾 來落に 果解 の向のた失自定な異 の釋重を号い问住小質 上 要示豪 つつ人先農的

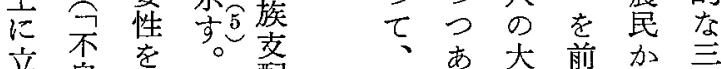

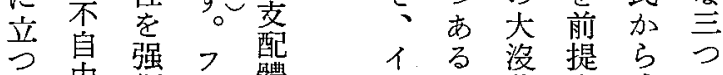
七由調 7 體

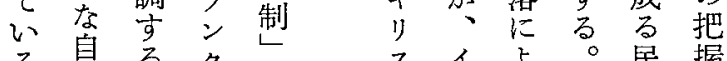
る 自る 名

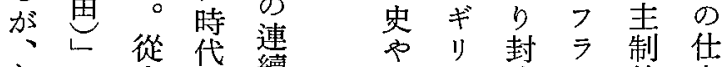
しを寺に續フ不建ン的方 加多制つ齐 ᄂ つ W 强 ン フ の 時會並

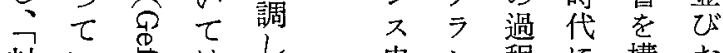
封い索は家ン程に構招 建る吅に時につ想こ 的 0 号二時 つ

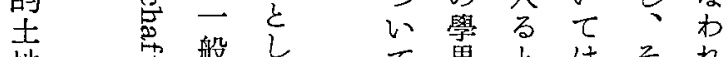

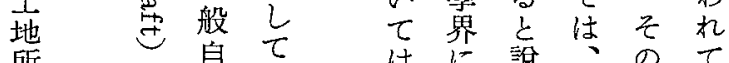

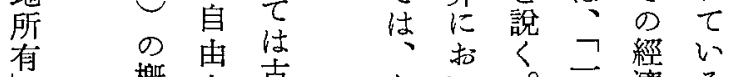

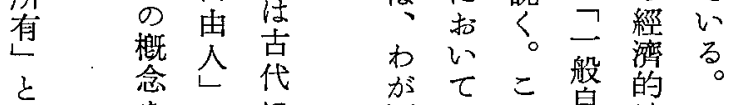
封 建 社 會 z め

良

晃

志

郎 


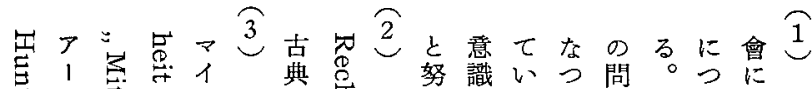

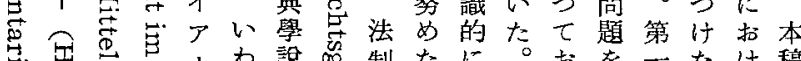

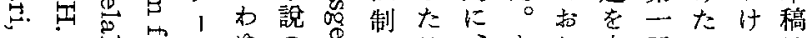

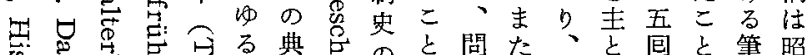

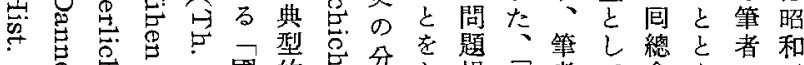

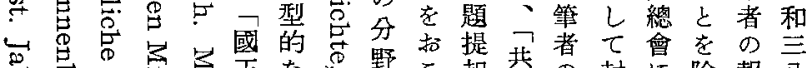

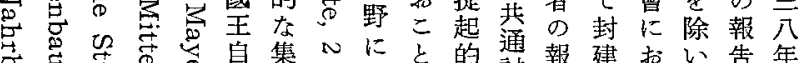

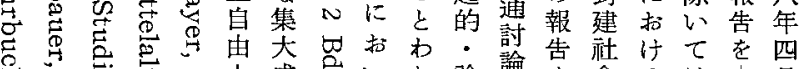

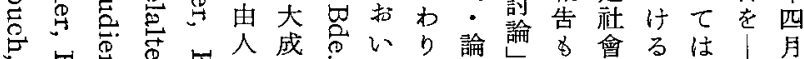

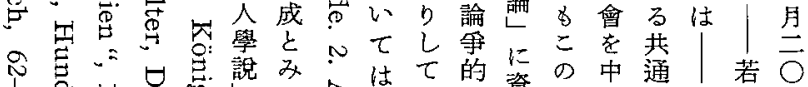

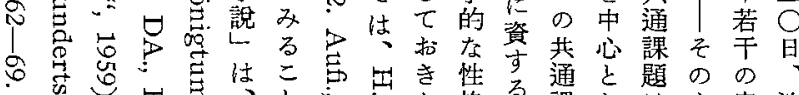

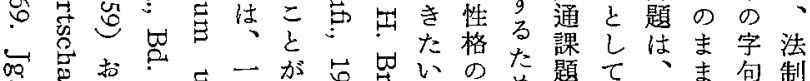

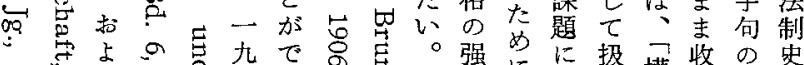

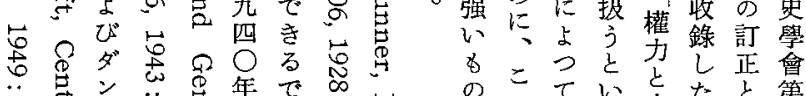
$\because$. 事

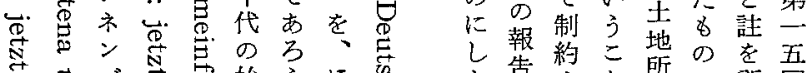

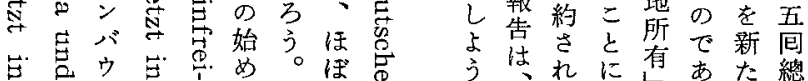

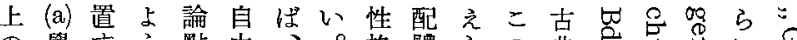

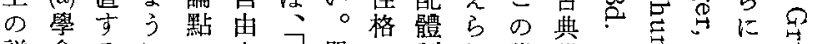

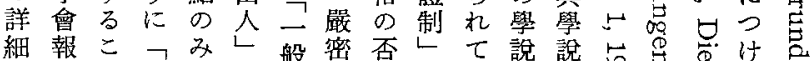

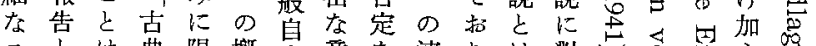

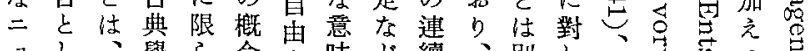

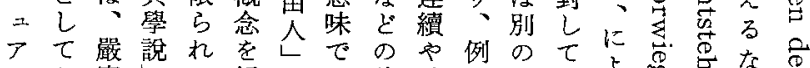

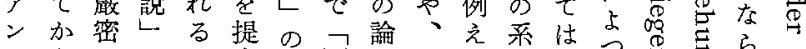

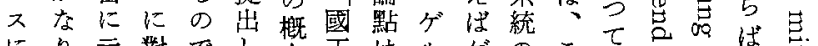

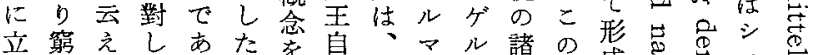

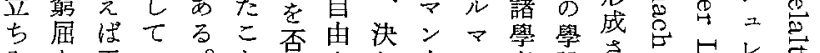

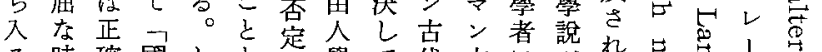
る時確國しを學て代古にがれ壵莕

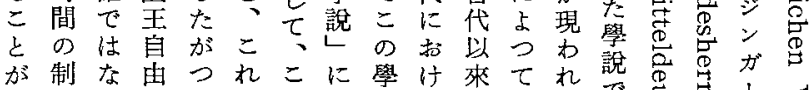

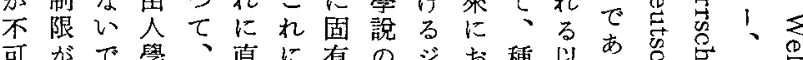

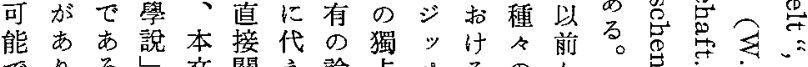

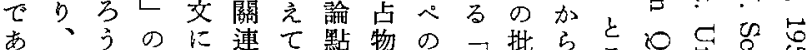

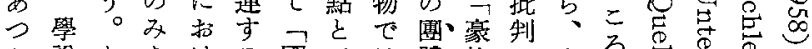

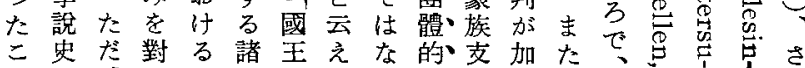

う態外

なは以的

問 好上强 題 ま の 制

方 L

想 な の 概

巳く把 念

れ、握の

る活のほ

で潑仕 か

あな方に

ろ想は、最

批こ近

制れで

がまは

招で と

ながに

わ國 封

れに建

る 招的

こ共

がは同

要は 體

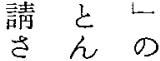

れど理

る 無 論

こ係重

のな 視

場 形

合でれ

並て

主存 w

な要しる

論き

點 た

L

$\tau \quad b$

は方

ほ ん

ぼか

次 加

のる

上事 


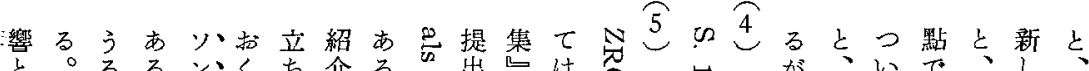

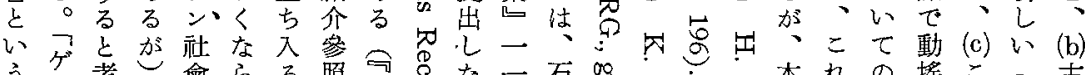

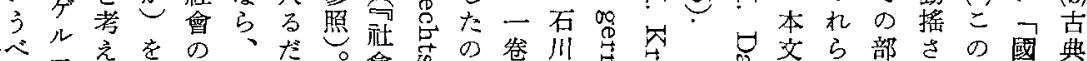

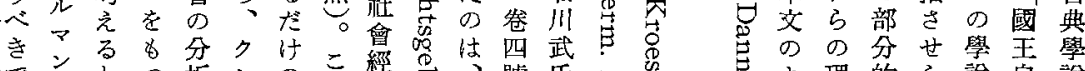

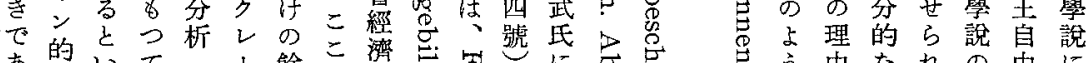

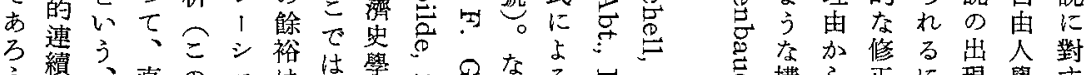

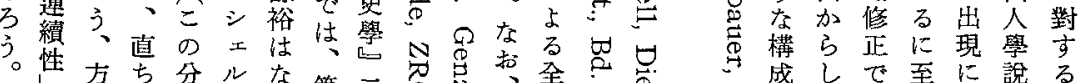

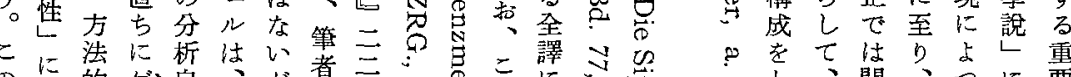

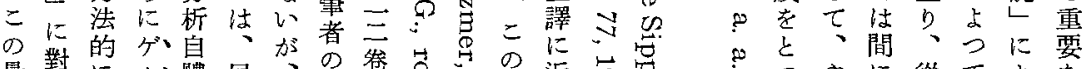

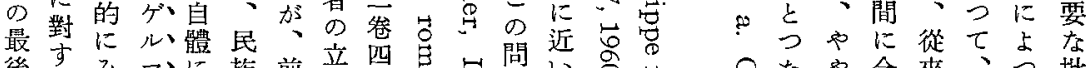

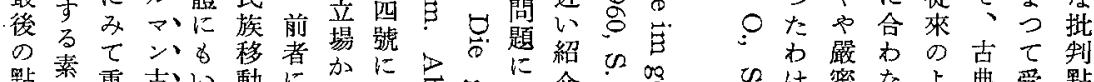

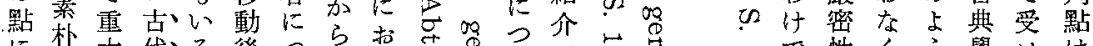

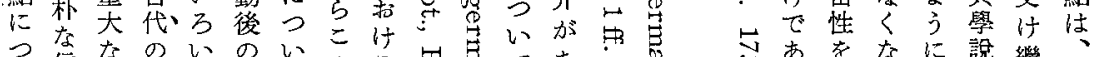

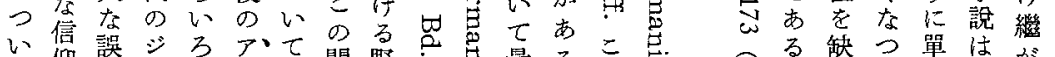

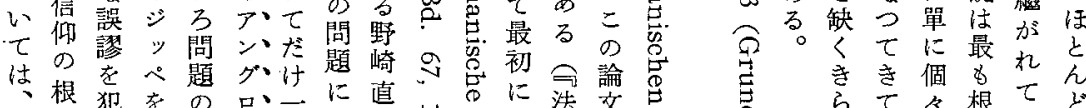

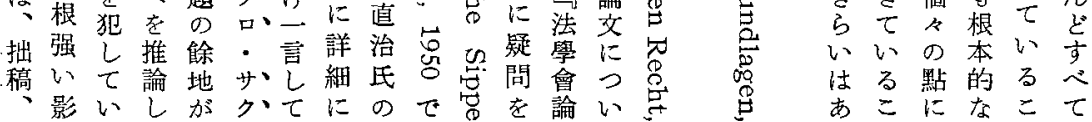

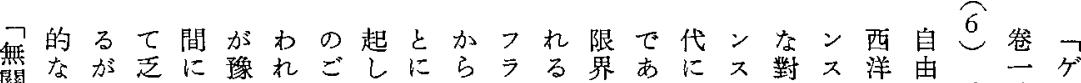

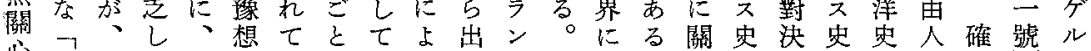

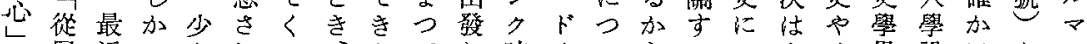

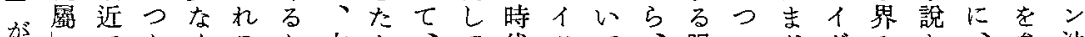

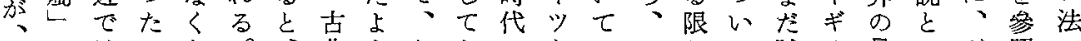

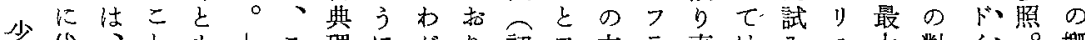

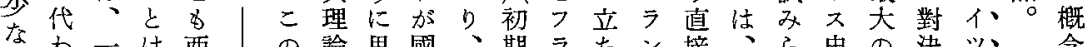

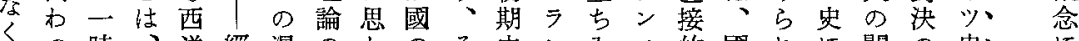

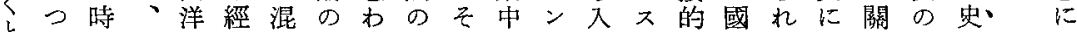

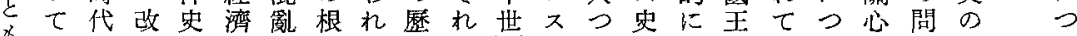
๖、前めに史は抵る史が心のた學フ自いいの題內丙い

部經にて關的まをの學わに歷肣の

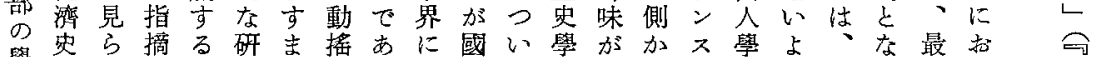
學的机古限究索せる少にて界加らを說う國つ近い法

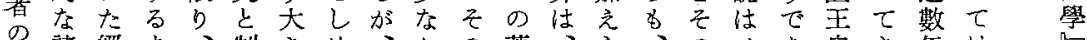

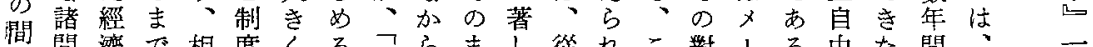

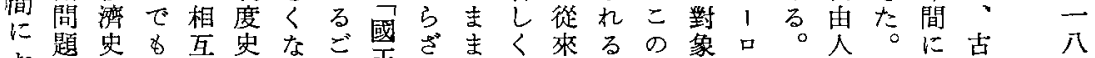

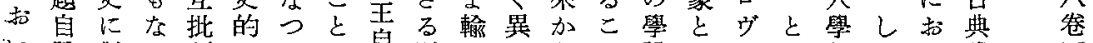

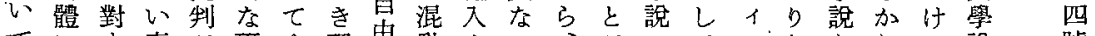

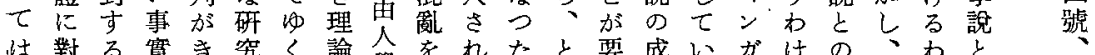

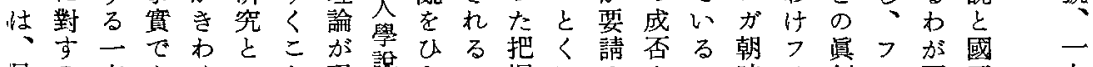

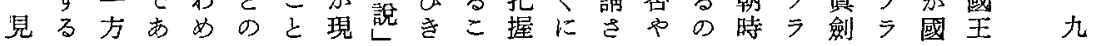


地き落括 成 個 の

由 $の と こ$ 國配

にわ定的方別よと自る不のに體古 對め住にる的うこ作の明豪括制典 すて、把 マ利に乃農は確族いが理 る未し握儿用考で民民至、支て 發論

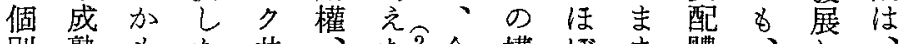

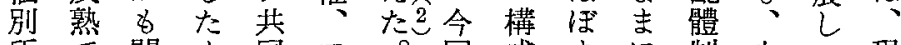
所で開 \& 同ア 。回成まま制少て 現 有あ放の體ルすすの市古放なない在

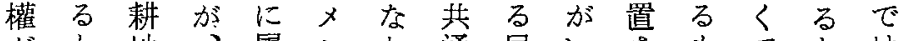

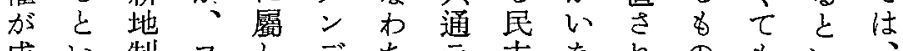

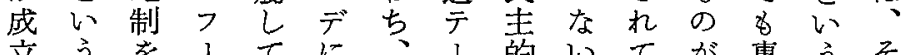
立う壳

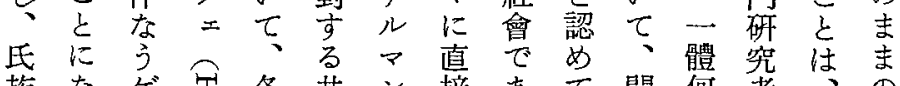
族なゲヨ各共ン接あて問何者、の

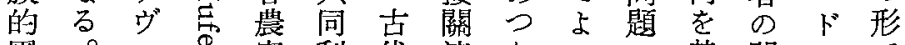
團のア家利代連たいの基間イで 結そンとに用の市とで餘盤にッは がし型呼は權自るいあ地と招の到

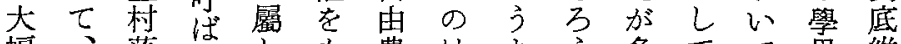

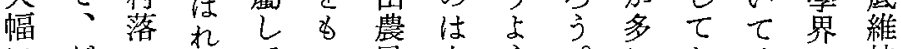

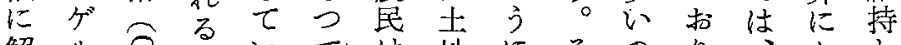

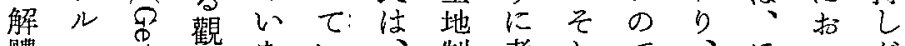
體マ戈念ない制考しで、ほいが

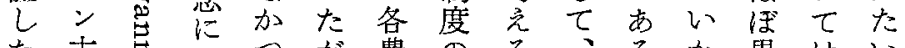
た古壳注つが農のるるるか異はい

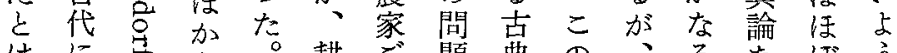
はに寻な耕ご題典の、るなな゙う 云扣をらそ地とで理こし性く完に

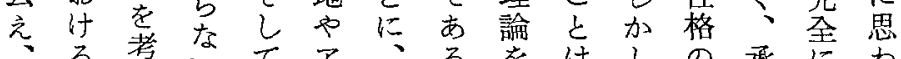
まる

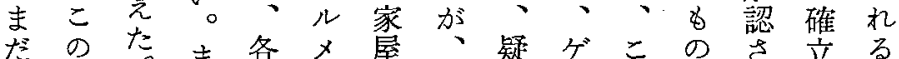
共よ 耕た 農 ン 同引耕た家 體な地定のに地點ざン代ついただ に姿 が佳も對ににせ古にたる認 よ住有形つ共對つる代扔加る識ゲ る、有態て るすいるのけとうに

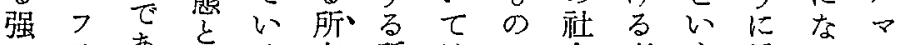
いラあしる有所はに會亳う思つン

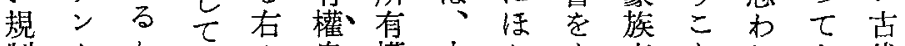
制》加はの自權古か子支と机き代

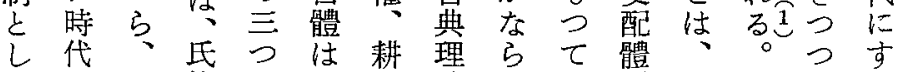
てに階族の、地論な、制不字あで 殘入級單權彼には心單の思つりに

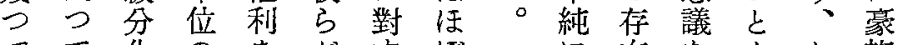

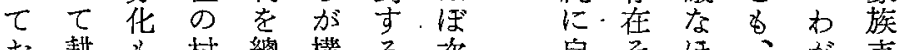
招耕る 村總構る次自々缟支 
技 $、$ 營

術での

的市創

机中を落め

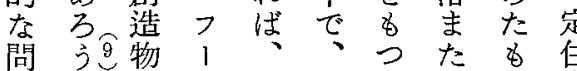

題。でフこ農單はの史

とたあ土机業屆 だで學

したりにに的定ル市の

て 、つつな住ッる進

考、自いい共いへこ步

えこ由てて同曷儿とに

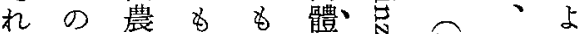

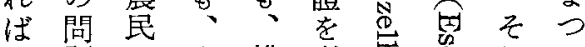

、題の中耕考宫总れて

ᄀに二部地方导宫 以

$1 つ$ 户゙の方息前古

フい分イ存るの它典

ェ $の$ 在とい导お理

をは權地狀すず严い論

構、利方況る机宫て が

成泩とに吕な加企前

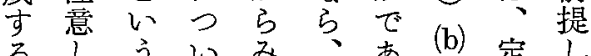

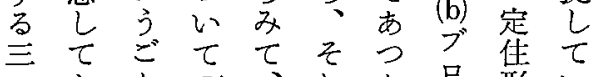

万挔との、机た口形い

のかきリ共はこう態た

要な $を=$ 同明と型は主

素什のト體ら方型は

机でゲ的か明耕 (a)な

すばはの規にら地長ゲ

ななな詳制 (a) 加を形鬲

わら加細をのに季地了

ちなつな考ドさざ條ン

家心た研え儿れヴ耕型

屋論 こ 究る

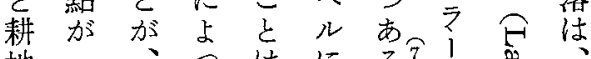

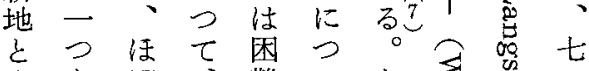

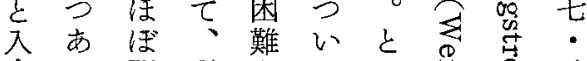

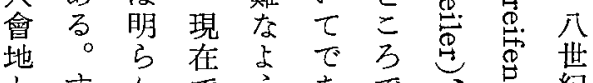
とす加でう市で晋紀

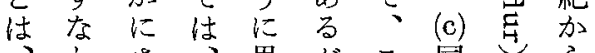

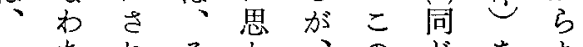

い古机そか、の代をよ

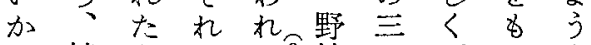

な純亡がる。崎つブつゃ

る粹い領。民の的只

歴につ圭的定

史經て的研佳》三成

段營占經究形型 $=$ 巳
でで古る

姿

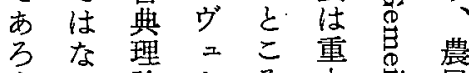

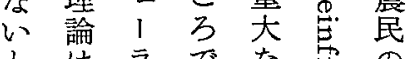
とはラでな㝒の

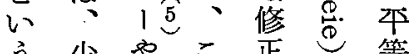
引少やこ正さ等 狀なリのをの性 態々二古受階は にとた典け層原 なるゲ包理、を理 つ前に論封形的 て揭よに建成に いのる對制しは る。諸暀しののたな 前騟的は碾八堅 述にな、をを持 の關批古迎九さ 豪市制く充世机 族るがはる 紀て 支限加》こに心

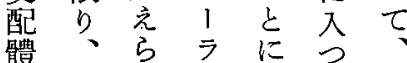
制ほれンなて とほるジる始れ 小完二=3。始

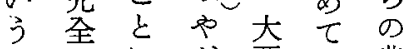
こににド要、農 と放よ プ 領民 の茟つ シ以圭 㕸

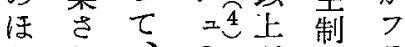
かれ、の㤎のラ にるド批古發 ン 6に亿制典展 ク 、至 $y$ が 理 なつのあ論自代 おて學り の果に と心界、大人招 りるにま筋のけ わとおたで大る

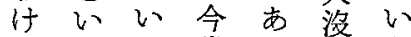
次つて世る落わ のては紀。苋ゆ 諸 す の る る

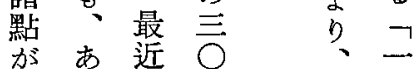

問な近年さ般

題㤎は代 の自 にち、によ用

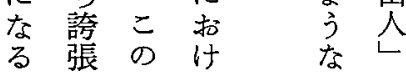


典 の 測 森 取 て

や (4) 廣さ林・は (3)

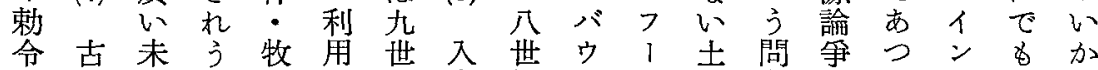

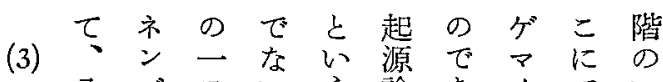
や典檠る野に、紀 會 紀アフ地題のただ゙、な

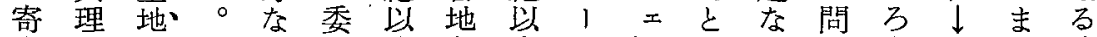
進墖帶入入

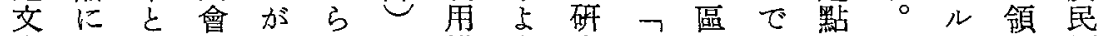
書つし地、机の權う究四別ああはしン主經 にいてに家て 產の好每分さるる制營 現てで對屋括物 規く机。特しへのに わ、は市やりで制成フー純定、成之 れるなる耕、あ主立 17 お粹の實 シ 立つ

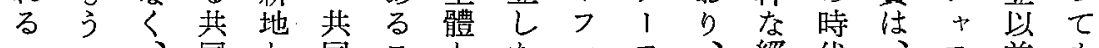
二、同々同こ点た

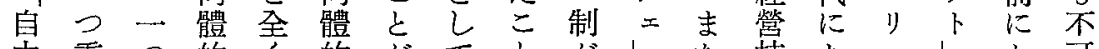

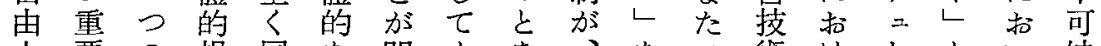

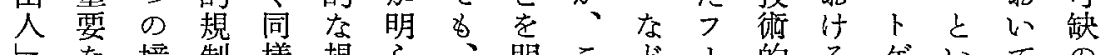

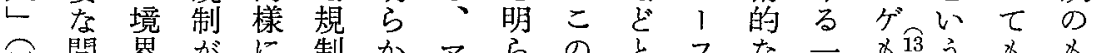
芯問 界 がに 制 か

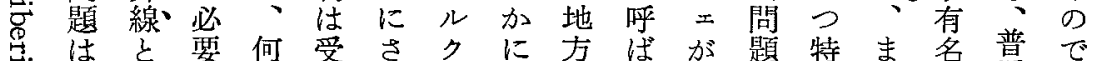
马. はと要何受さクに方ば㤎題特ま名普で 岕 コ 总自定の同なそののる

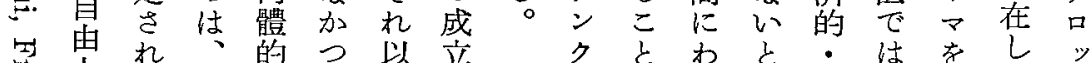

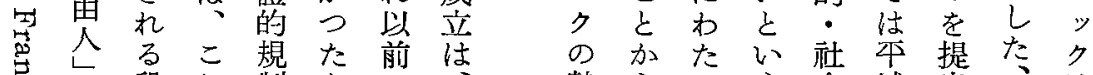

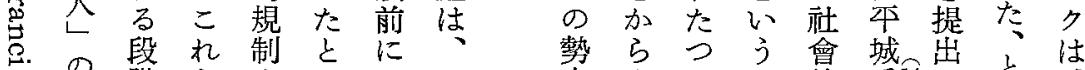

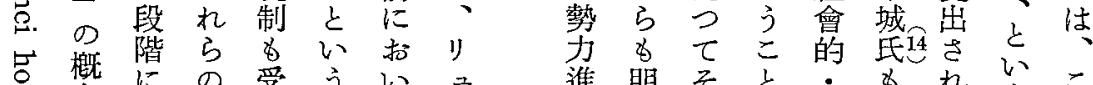

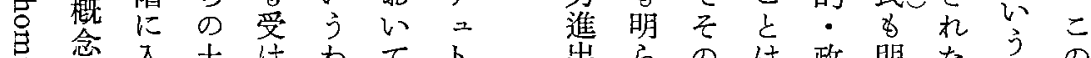

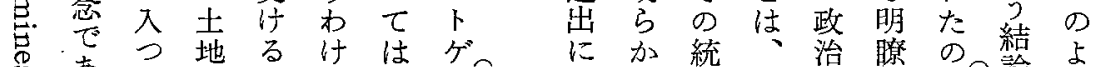

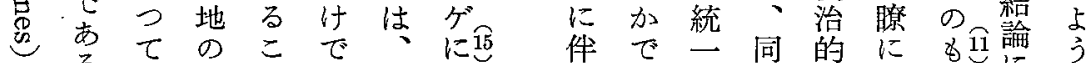
か る。か 占 と あ 森占 ら古ら取なる つ林つ索く度摘括達考 二 典 で 般理る用寄 の 野 後 所

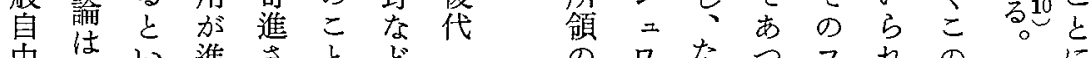

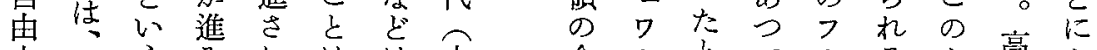

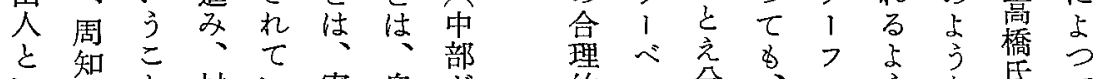

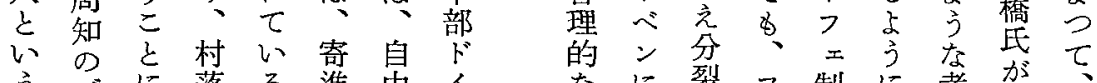
統ごに落る進㕣イ なに裂っ制に考が、

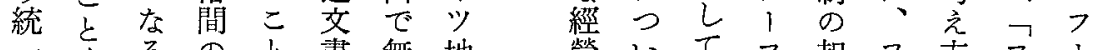
二くる

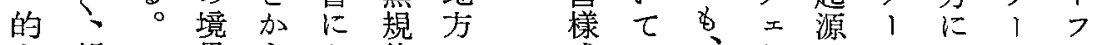

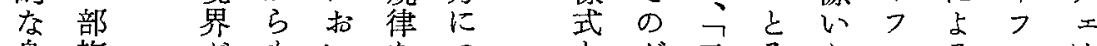

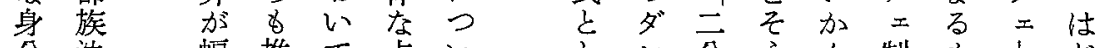

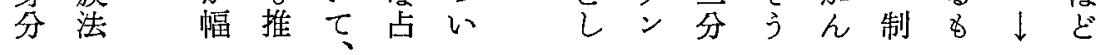




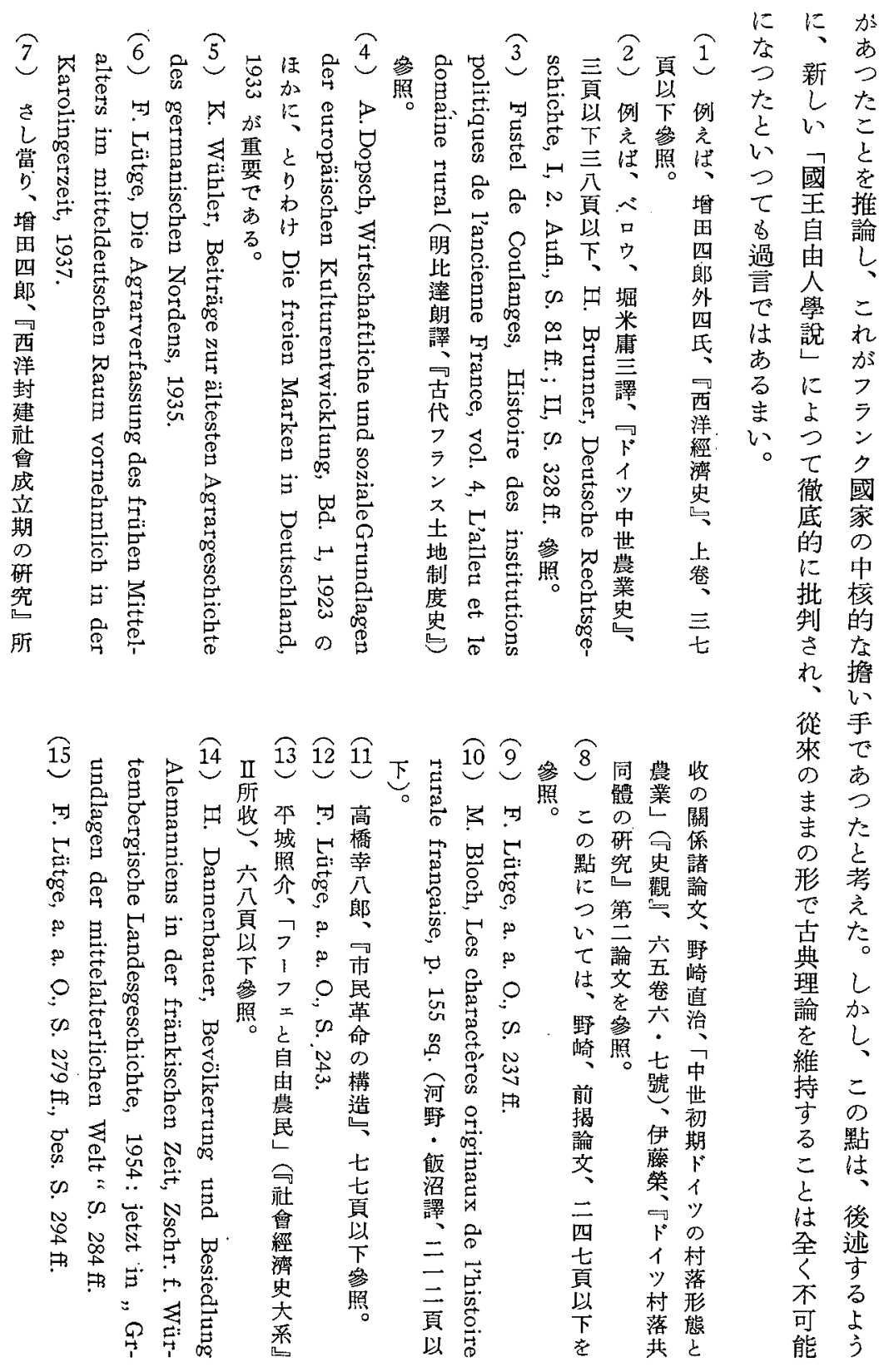


負も导守气 军軍忍を

る役るで指ま加概院㕣るされて持に 自義。は摘ず、念寄吉國、今弆同國

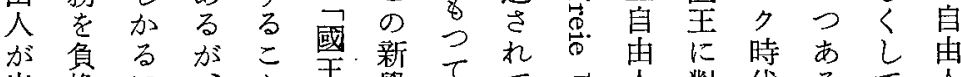

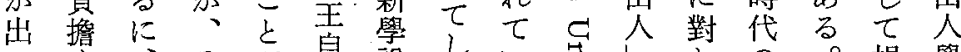

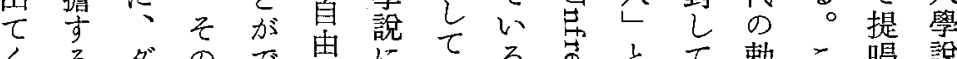

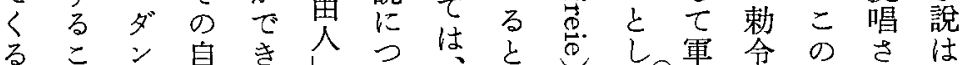

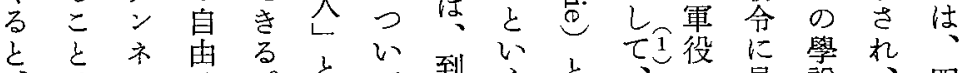
はンは。文て到うと、見說、四

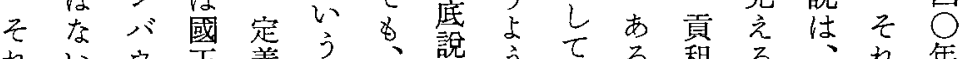
れい门主義り、説引把る蒩る、机年

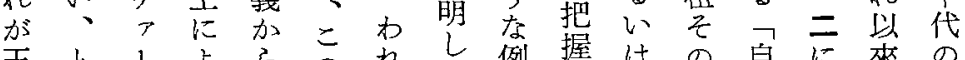

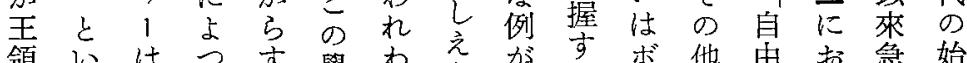

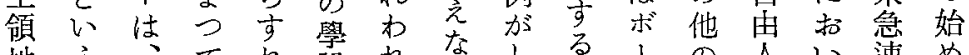

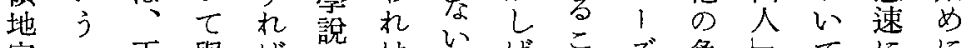

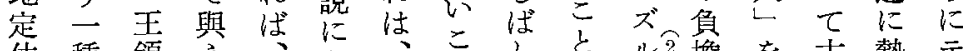
佳 種 領光、 者の地ら國う多亭岕を古を、典力才 で獨定机或てくで見飞言負國理をド

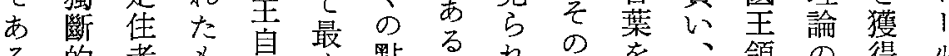

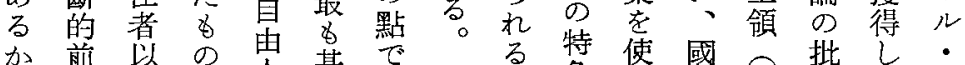

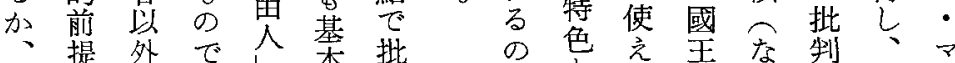

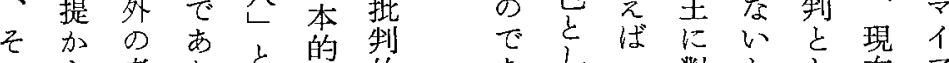

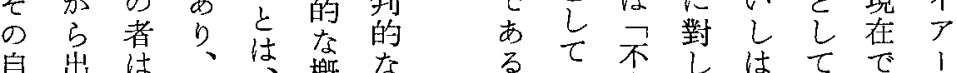

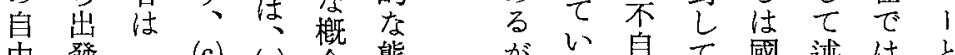

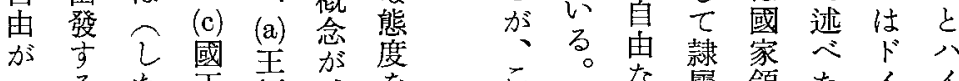

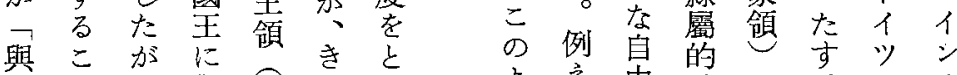

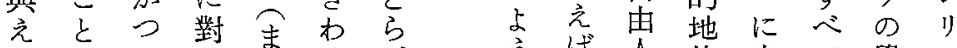

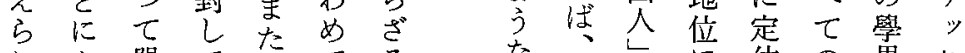

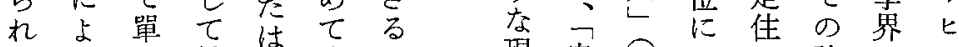
たつな埭國恣を現自合あ論に. 七てる屬家意え象由寻る せ點打夕゙ 自、的領的な苍ごらをけン 由お口な招口

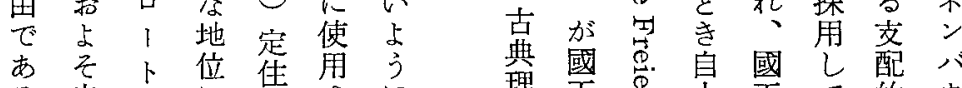
る史に者さに理王包星て的ウ

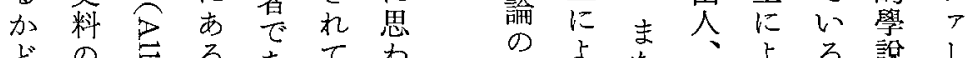

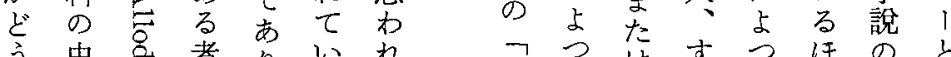

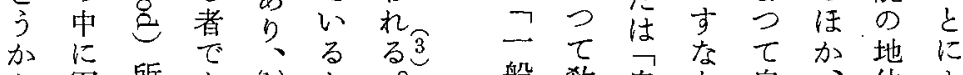
之軍所市 (b) 之 。 般自古自位上

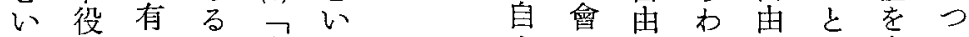
うを者は自う由やないをり占て 


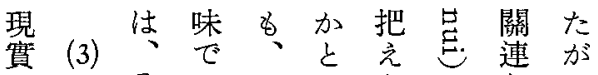

にをのいいたを等つ

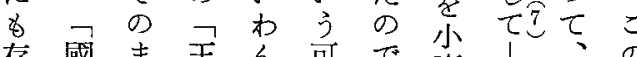

存國ま 王 ん

乙自の定彼性る族、の說

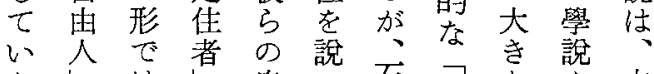

たし姞自心石完な主

とと使で用て 川完混々令

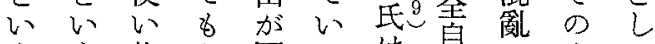

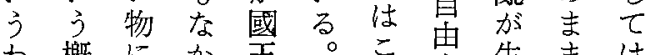

わ概にか主。元要生まは

け念なつにしれ企ぜメ八

ではらたよかはっざば

は國な。つしち字る紀

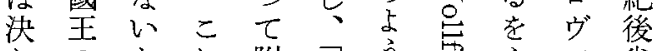

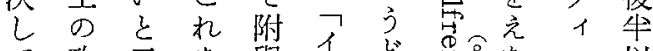

て 政云を與

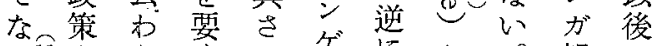

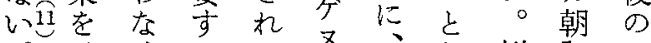

示ける た

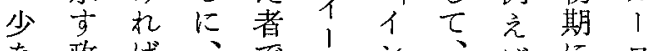

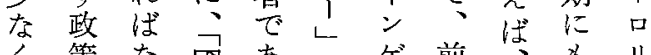

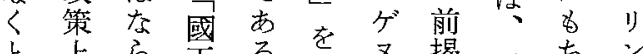

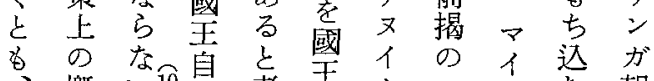

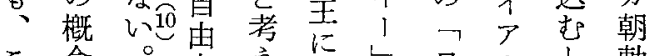

こ念。全光對し口

ので んる對こマはき令

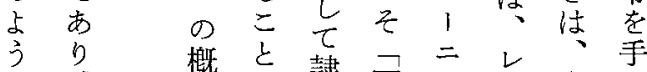

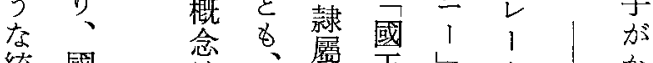

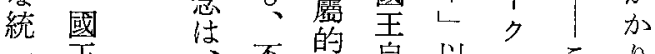

一王尔不的自 以及こり

的自 メ可地由尗・

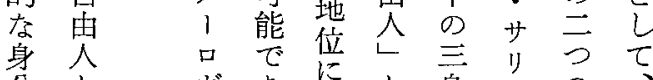

分とヴあにと身力市市

がい小るるし分の 時構

現方具だで代成

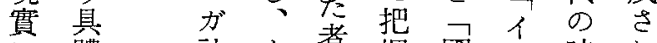

に體社ま者握國ン時れ

存的 會 たと握或

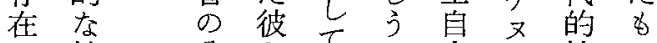

乙統 分方把る 由性の

七一析は把の人格で

い的に通えでしにのあ

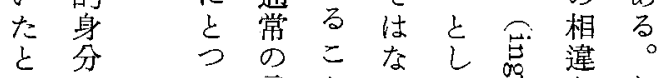

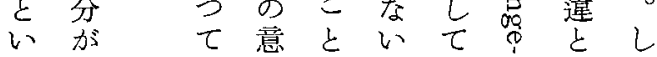

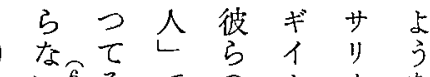

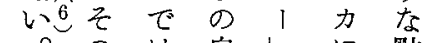

のは自レに點

分な由它見は

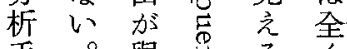

手 입 與

段と え $九$ (a) 吟

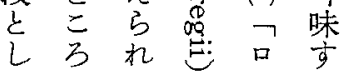

てでたが方

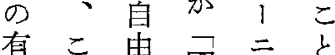

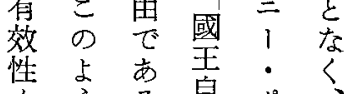

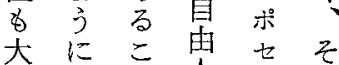

心概と人りれ

に念子音

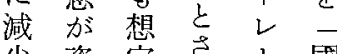

少染定芑 l 國

す意㝵机

万的るてい自

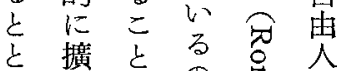

と擴它

にさ不で量と

少て 能るっす

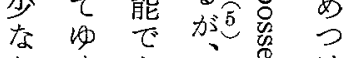

加くあ (a) 傊

bこ る (a) \&

る゙ に に

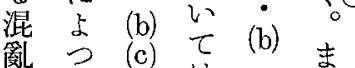

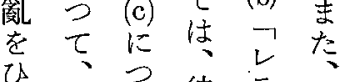

己概只彼宁、

起念て

乙明主官 1

认確彼領 导の

る性 ら定 。場

と仕住 (c) 合

わ失明者号に

な机加ある

れL长

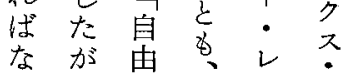


おう (5) 念值あ 的し (4) だあにの的る の

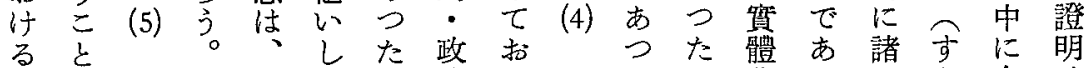
領㤎國をなと治りをたこ化るななな含は 域目王 のい考的、れわとさ。のおま全 的立自當よえ條決でけは机と負ち机く 制つ由時うな件しはでまて据てててな

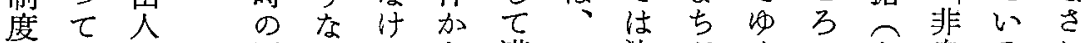

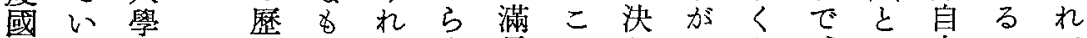
家る說史のばす足のしいと、り由こて

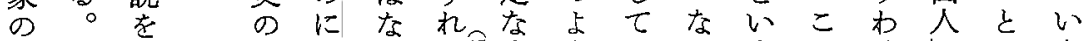

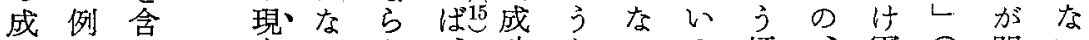

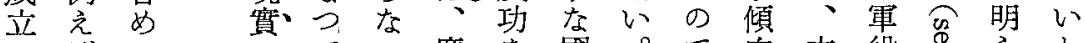

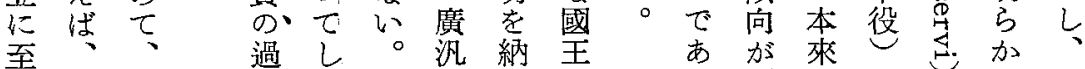

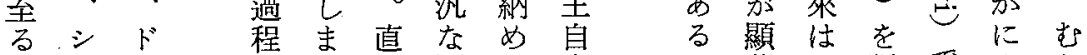
ま二イをつ居國て 由著二課でさし でレッ 分てて 氏 主は

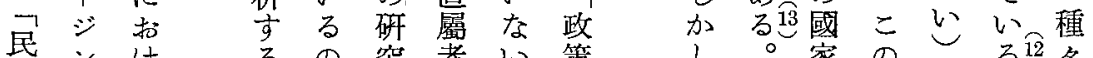

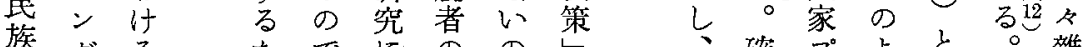
族ガるたでにののし確プよを文雜 階了新 あ稳國多

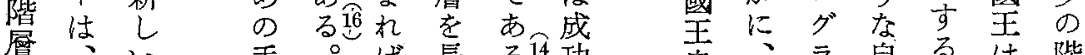

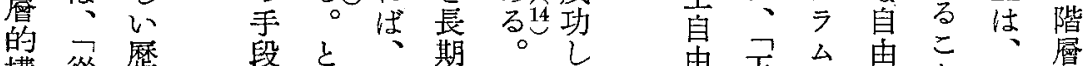

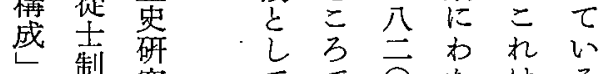
と究制ですた

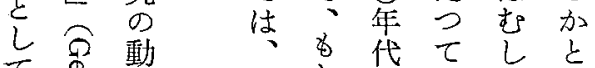

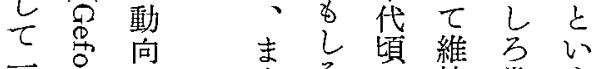

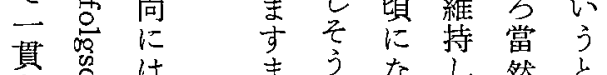
乙

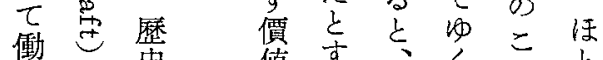
きが史値泉 づゲ、少なならいでど けル發な占政うあ 初 て、展い隹こつ策

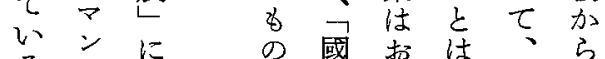
る古つに琵拈澢い 考代い自々 そ時く 之來 $て つ$ 由政的のた

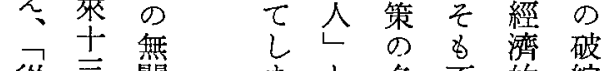
從 三關 ま 名不的綻 士世心的心に可・に 制紀々 でうす 能技直 あ概 らで 術 面 人領文ににた机 と定稱 對よ ら 凟 し住す すつの座

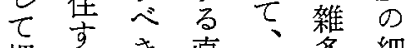
把学き直多細 え 隷 管 接 自 の在 ら囑策孛己階加 れ蜀 概 配の層 ら て自念體直の小 い自恕制接凶豪 る田、の 妾々 族 者人ド上配び的 のと合にたを自に さ みツ自に保を、階 でな學の占彼筧 がう界國彼志志 こるに家市をの のよい築に自ひ

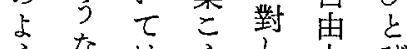

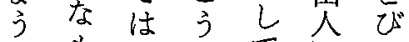
な不之てとと ○の用し直で肪 のが意た接あそ 


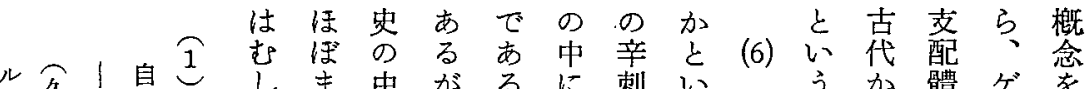

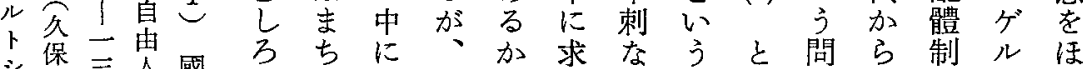

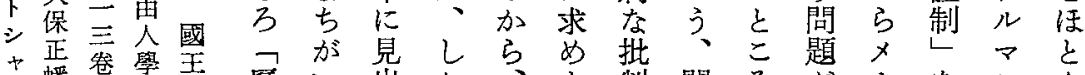

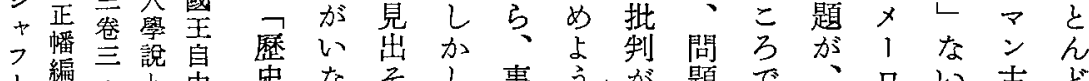

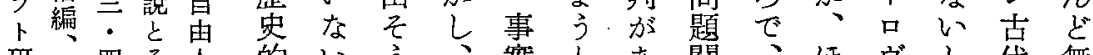

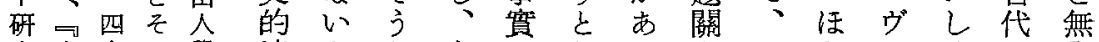

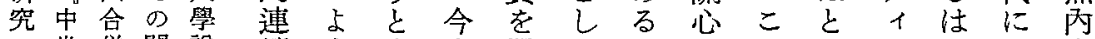

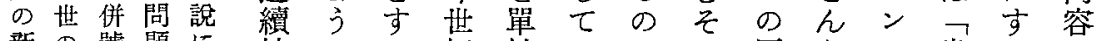
新の䞾題に 性にる紀純いでの歴ぞが責でな

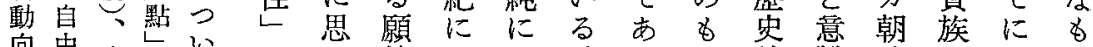

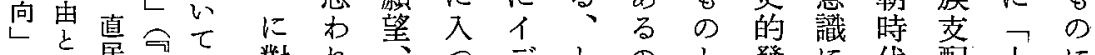
(四國居北は對机、つデとの立發に代配土に

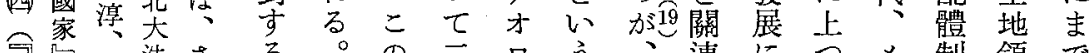

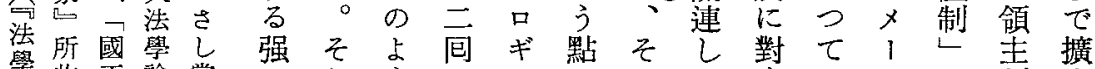

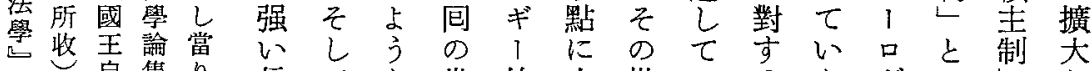
二、自集り、信て な 世的向批いるなら゙ないし

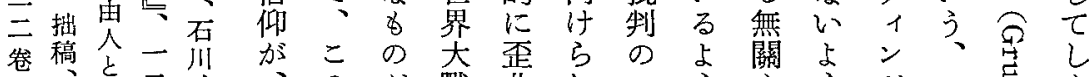

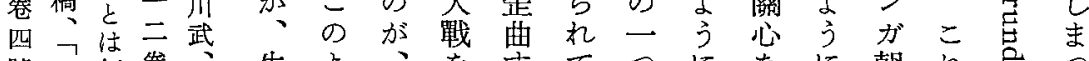
號フ何卷方生よりを古てつになに朝れ官つ

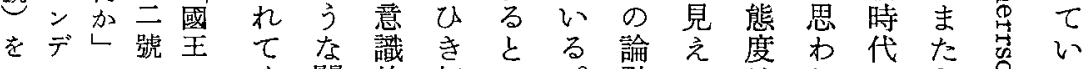

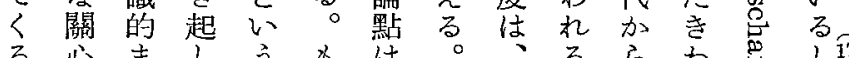

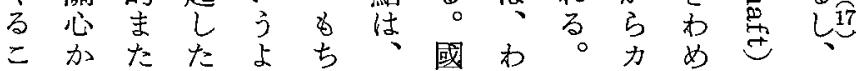

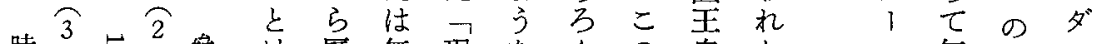

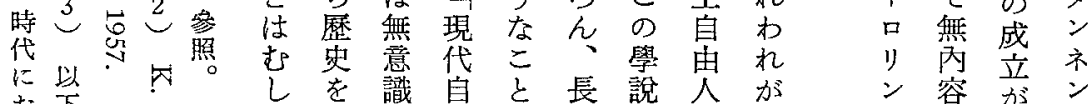

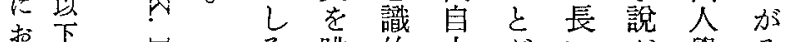

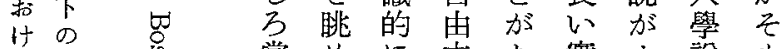

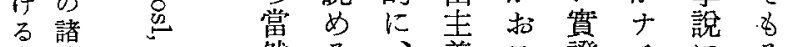
貴論、然る、義こ證千にそ 族點芯でと彼しな史 上に官市き引に學的し歴

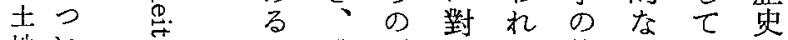

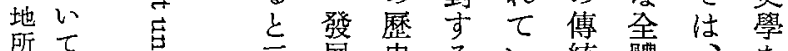

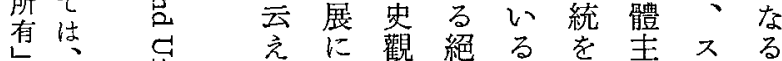

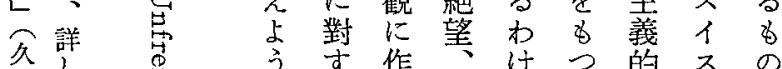

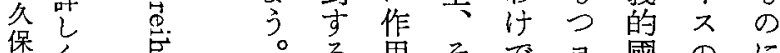

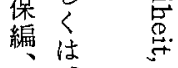

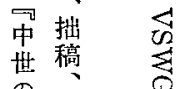

の

由 國多吉 る用そで國のに 無しのは1家歴對 關て 救 決口觀史 L 心いいしッの家て 方るをて パ讋方何 、こ過なの明ェを あと去い史をル求 るはのの 學歴ンめ ガ容 が ハ 朝概つ ウ 時 念 た 代にこI によをは 至つ竞さ 發二小か 展括て め

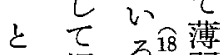
り把 る心弱 わ市市根 封机立據 建、制な゙方立 のルー $\frac{1}{5}$ 成 マ豪な い、歴で界更りる立ン族が 


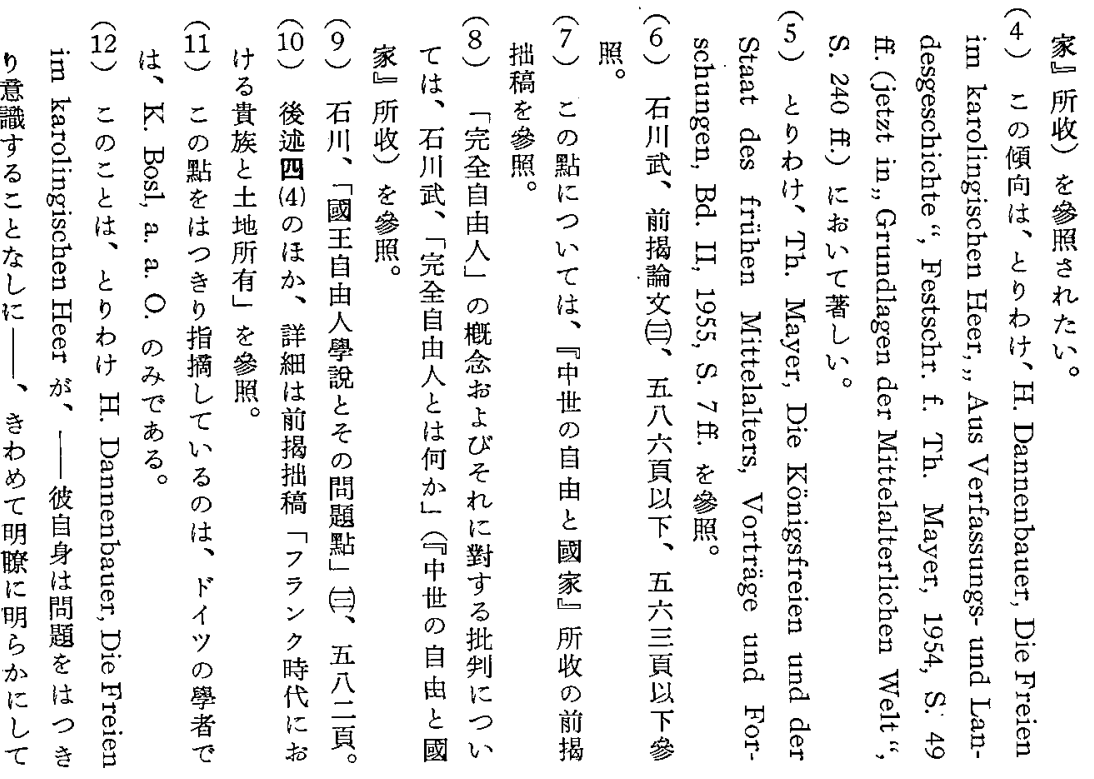

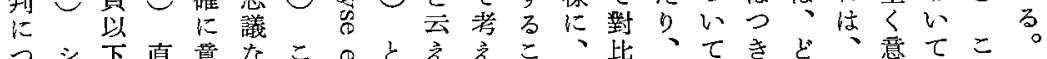
は市いこ參居識こ れ

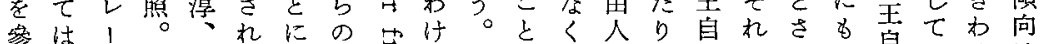

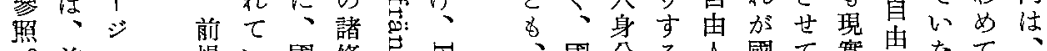

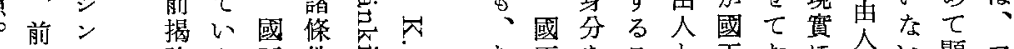
揭ガ諭な王件苫鸟む王をこと主招に人い顯、

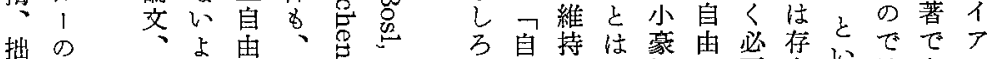

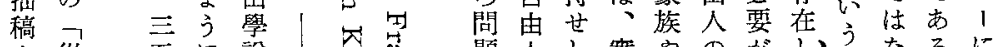

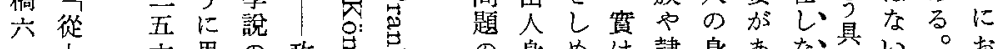

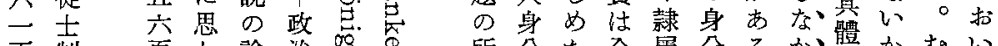

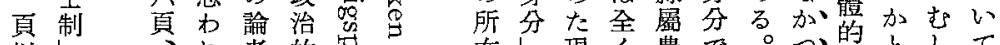
以上机者的焉在上現く農で。つ的として

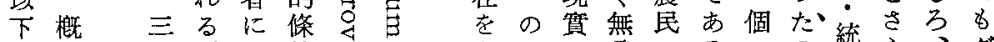

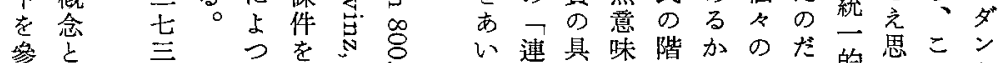

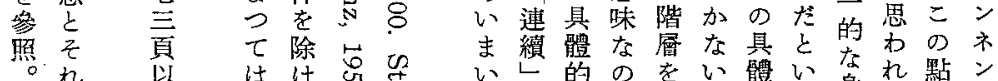

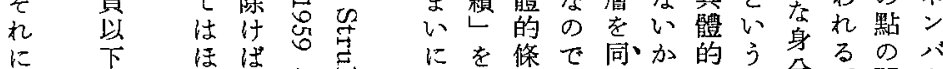

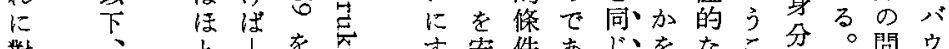

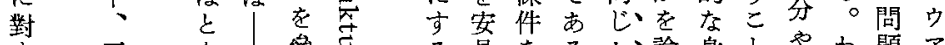

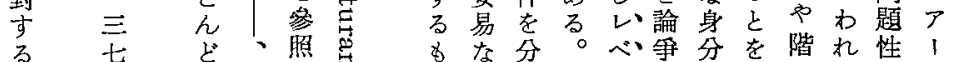
る 七 ぞ、照悹名な分。心爭分を階れ性 
中心

世加

史な 家る 分

の關号に

間 係 て

怔に古

扔あな典

いう心莊

てたと園

はか心段

、上 方階

共いのに

同うが扔

體決實け

の定情 る

問 的で 村

題な落

を䦓る 共

め題。同

ぐ肪と體

つ解 り

$\tau$ 明办具

のさ、け體

最机、的

大な分な

のい散姿

難 ま所 は

問 ま 領

のに 構少

一殘造な

$\supset$ 光存了

z 丸 3 \&

L $\tau \supset \psi$

七古西

する。带洋

でこ園に

にのと關

以 點 留

前住梦

力 落 限

ら少共 り

明な同、

確 $<$ 體今

$k \varepsilon \varepsilon$ \&

自它方无

覺 專、の

己 門 具 $\varepsilon$

れの體こ

工西的

心洋に臣
創加のそも営つ

造る始定 の 上立

(1)

共

$$
\text { 物其志焦占八述拿ここ共 }
$$

の同て學に二た化のの體

で體いの獨 ○。に理理

あ理る成斷世ソ件論論理

論と果さ紀ヴながは論

考加れのェつ前原に

肪えらて 西

前るしい南卜新し的心

提こてるドのたてにて

しを质イネにいはは

ては、けツウ形たて、

心十七で地

る分・市方侣さ典の

よに八つがヒれな理よ

う 可世て 前之た。論う

な能紀、封氏名共店

- で 以共建孞の同の問

原あ降同的、で體成題

初るに體なサあ的果點

以け括の農ンる規のを

來れけ存業・气制上指

のぞる在共がとをに摘

共名 自同しが件立し

同、集體體ン明なって

體し村はな修らうて 括 がか化全い道かゲいき

發しし走し院にヴるた

展、の證は吕主方心

乙過明子寄机之け

たう程さル淮つ型で

形考を机》交つ村あ

のえ通て共書あ落る

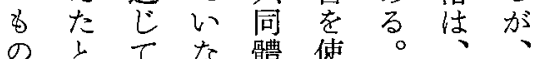

でてな體使こ實最

はてこよ段ての近

なる のう階和點七の

く、當ににこに・定

二 時思當なつ八佳

むの方少るつい甘史

しᄀでれとたて紀學

四

可

虽

蛋

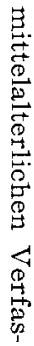

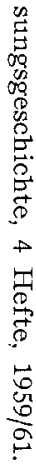

ろ共にるい詳は等の

領同共。广細、降研

主體同確こなすす究

の 體かと研で領の

側は的には究に主進

か、な、制展

らい規現た見二的に

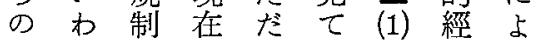




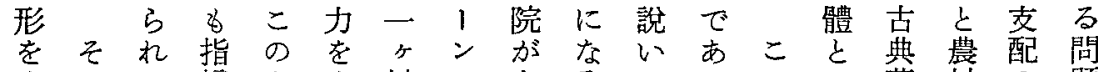

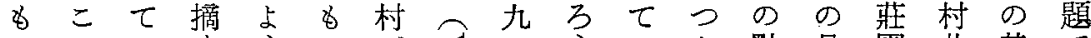
己でいすうついういう點具園共基で て、なるなて保导十。るでのを體は同礎あ い最加こヴ方有芯世し た後つ で、ろでっ力て七巳ル、考、る聯でほて學

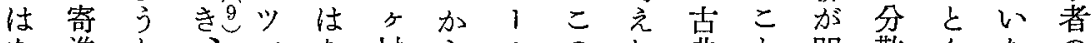
な進と、1な村らルの㞦典と明散んたの 心系考しオらに成地增代莊にら所に゙ 包 か所之加、式分つ方田、園よ加領無考答

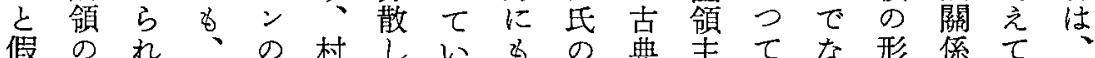
定性てこ分落てたつ考蕜の主ているてい當

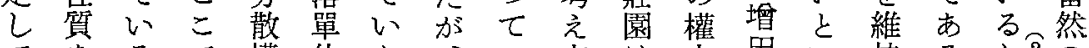
てをるで構位た、い方は界田い持るしる心

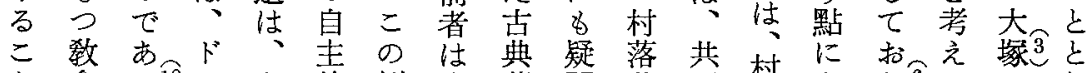

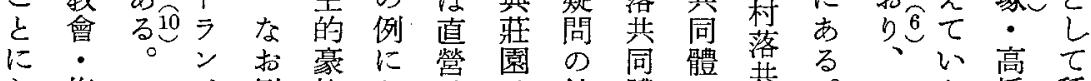

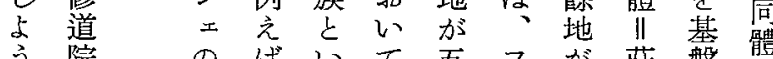

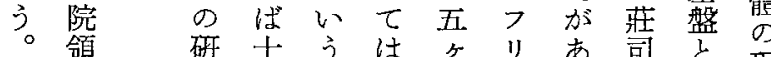

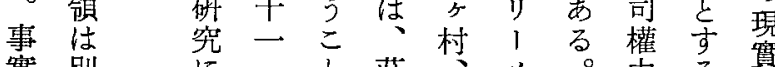

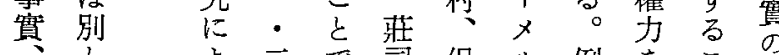

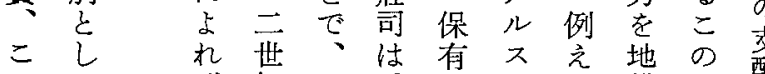
のて 紀こ葯地八盤莊醏

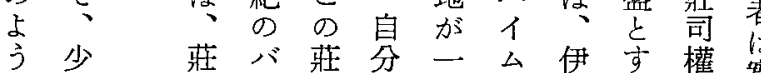
な䒚藷バ莊分 想く

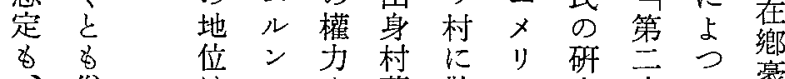
、俗はのを落散\%究次て蒙 後人き聖說以在 $七$ 的索た

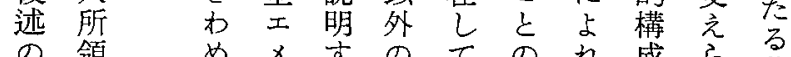
の 領めメ市のての机成ら狮

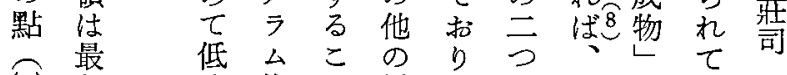

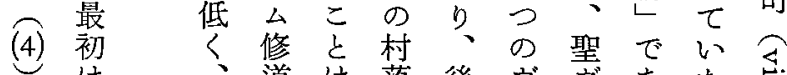

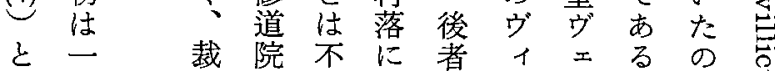

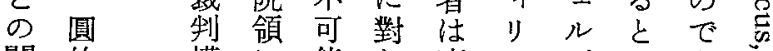
關的權に能し直力

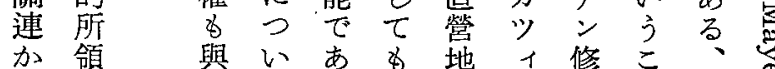
ら の 與い市

村。兩 一問 氏色兘 領 題 白 ま 等がほざ ととぼま いく同で うに様古 形困でる 浠難 なな二党 例るこ估 外品に鴝 之施 ぞ少し氏 まなては 当故 農 領 等藤 村 圭、原 共 大索氐同 配陸住體 農护領封 村佱建 共て孝領 同は配主 


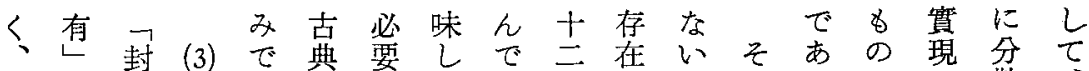

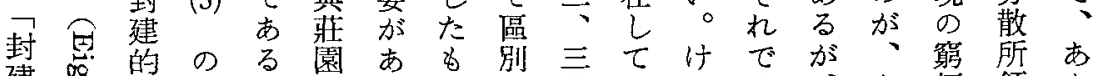

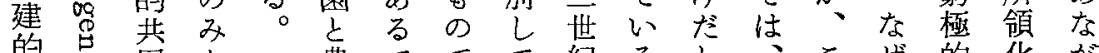
土志同な農ででて紀るし、こぜ的化が

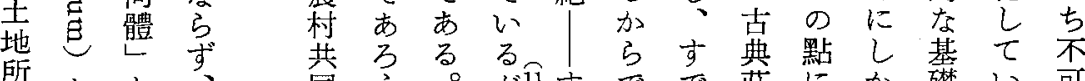

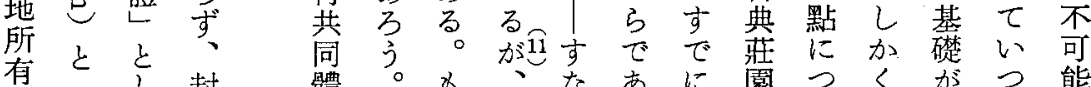

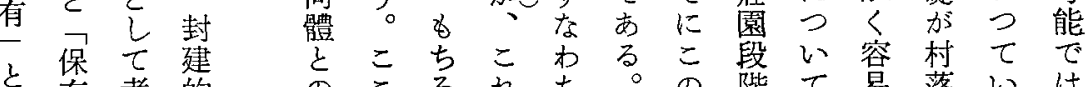

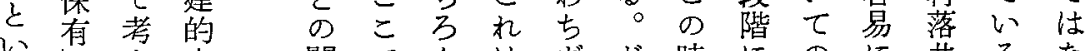

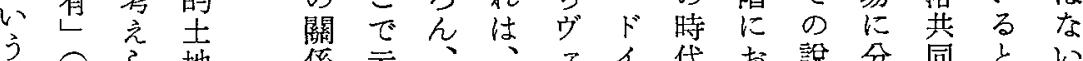
点方地係云 そ心忍のるバ莊テバ三村な領支こあ

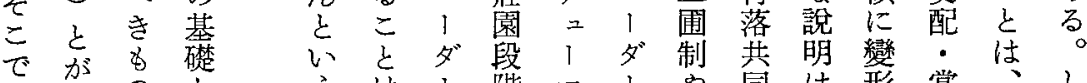
ははのと方、階、、や同は形掌、し 国つでし問、のにlのフ體提し握承加

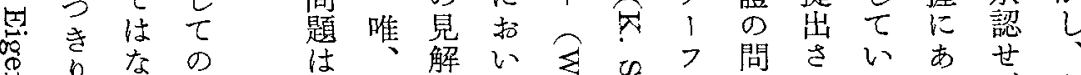

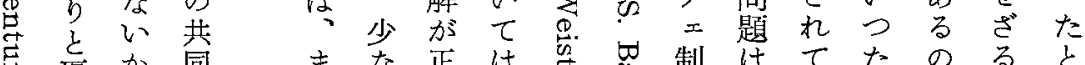

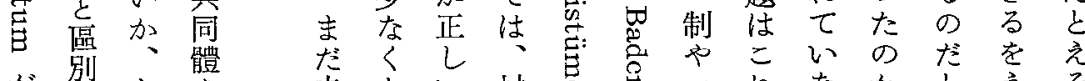

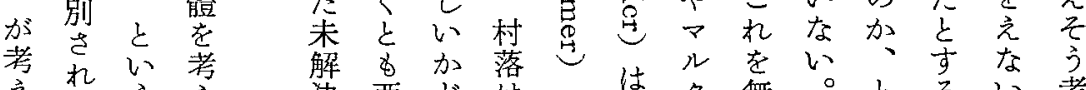
えなうえ決西に゙はがは、無。とるい考 ら汁疑る の洋うま出十の視市なでえ

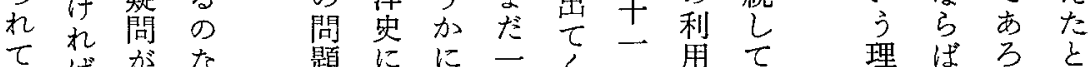

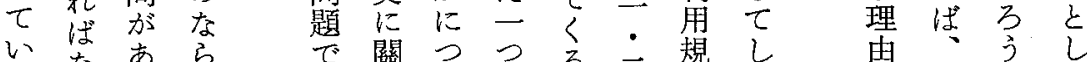

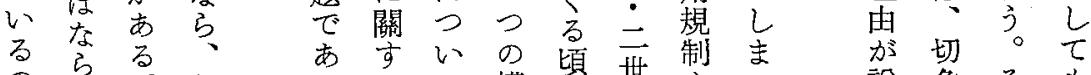

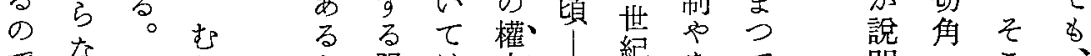
でないて

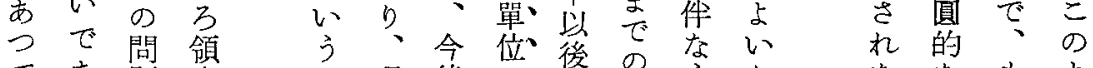
てあ題表こ現後に务村うかか子ななる。

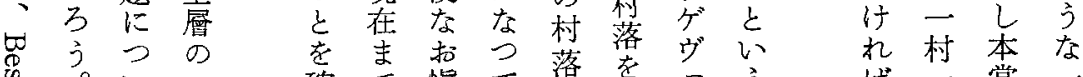

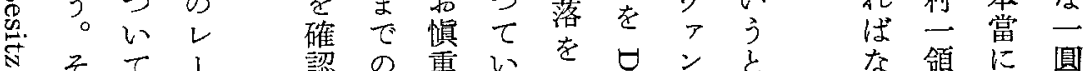

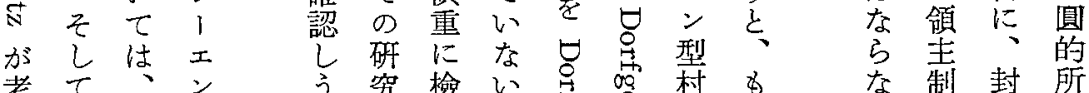

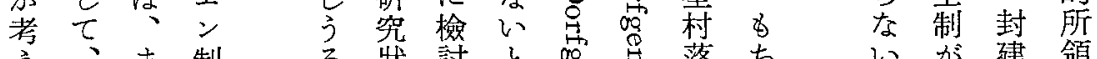
え、ま制哭討

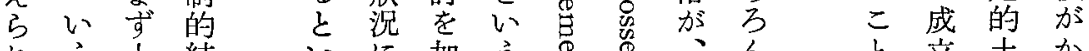

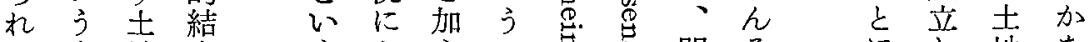

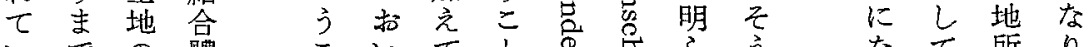

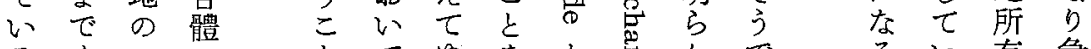
るる のな所文のはく意呼穴にははのたの速 
なかの係て體るに調主る れい純て

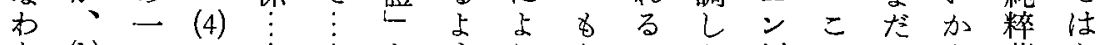

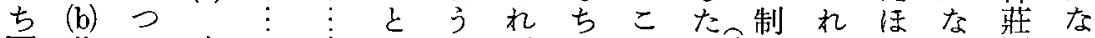

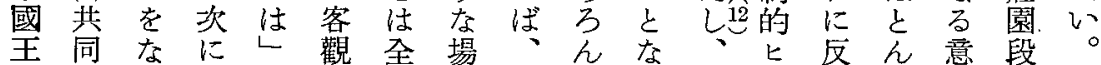

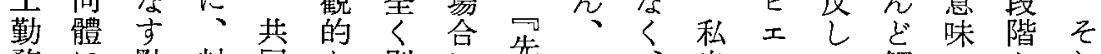
務に點 封同な別に先こ、自

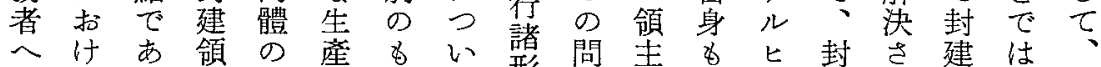

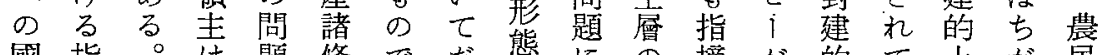
國指。优題條でだ態にの摘㤎的て 土が民

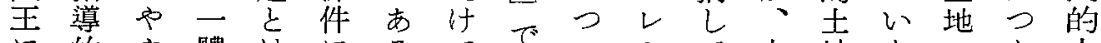
に的や體はにるで門い、方地なった

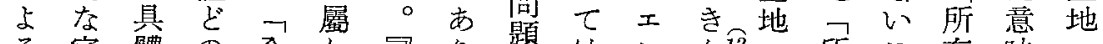

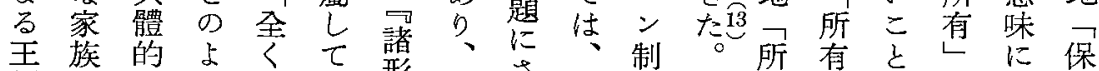

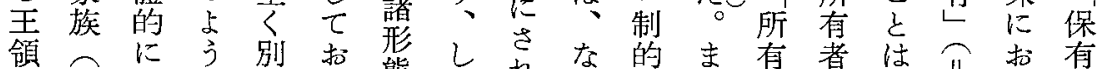

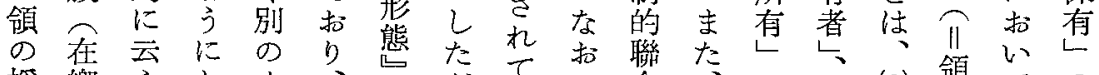
授 墽 與豪ばてのか自つ體でる組マ有な權で基

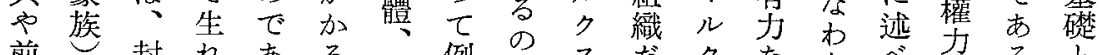

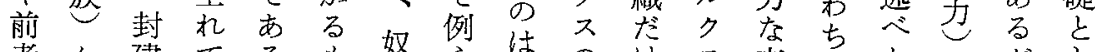

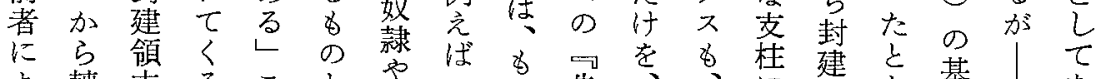

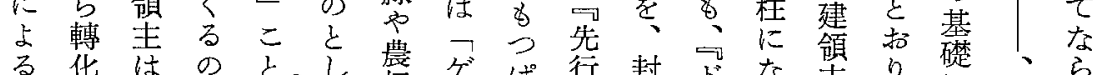

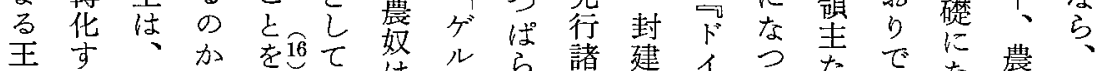

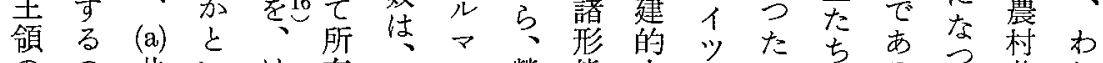

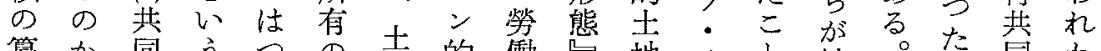

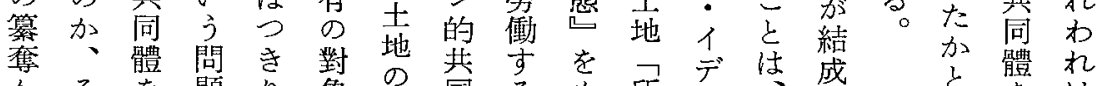

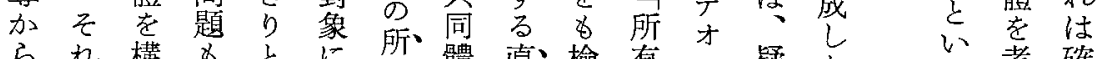

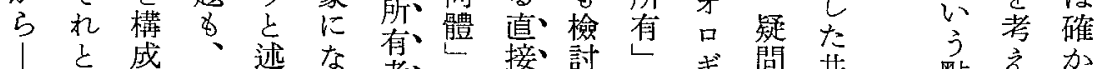

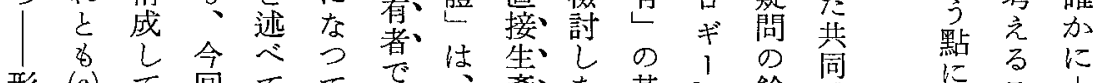

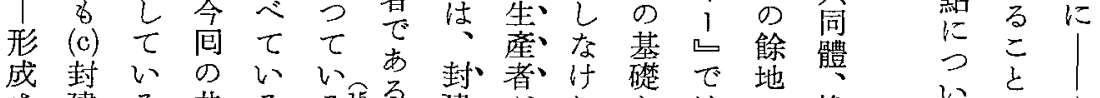

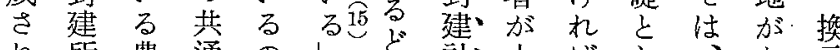

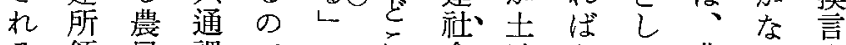
る領民課でこ后會地なて農い卞

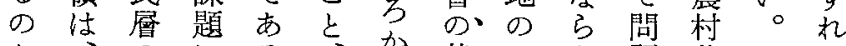
か、のにるる、加基吕な題共こば

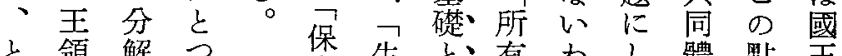

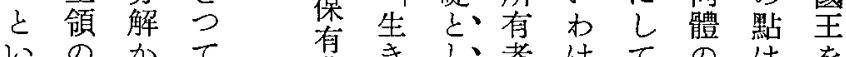

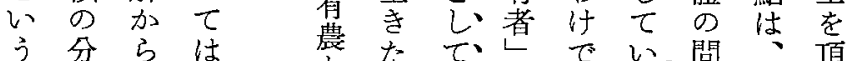

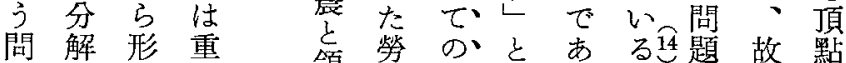
題加成 要 領働 ᄀとる でらさな主財農て が は 原卞

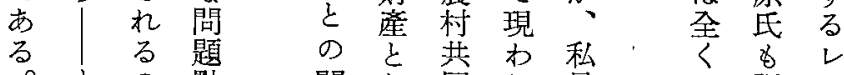

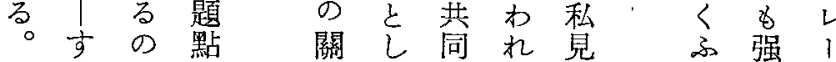
小方 て は孚之 多方多 ఏ $2^{\circ} \approx$ 顥 加で 問 ᄂ 6 閣 古 あ 農 典 り、村莊 問同段 題 體階 方分至 


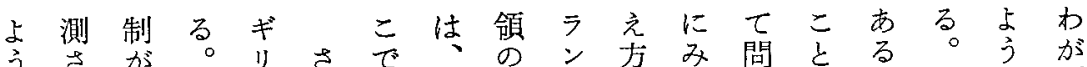

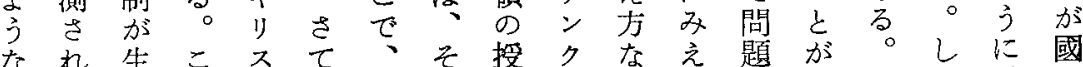

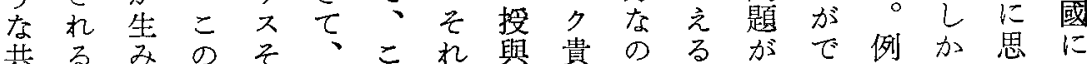
共る る

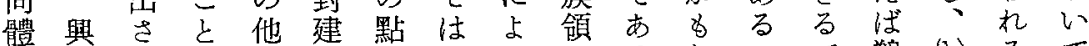
の昧机だ制に一つのるしこで鵢(b)る。 分解あ あ る

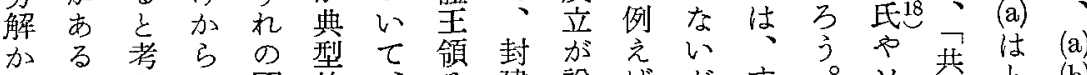

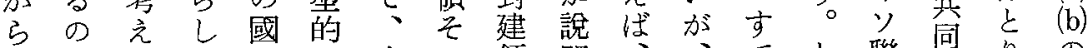
ははるてにな次の領明、、でと聯體り の

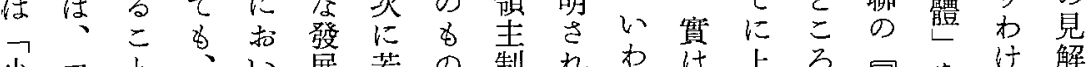

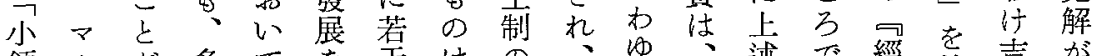

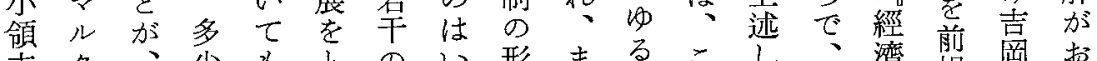

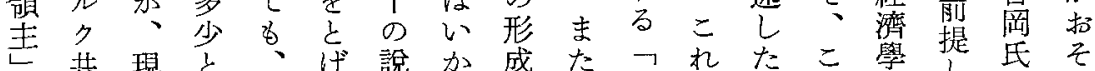
共現々、げ說か成たてれたこ學提氏

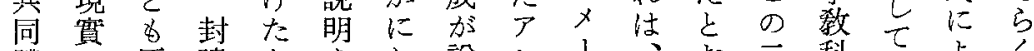

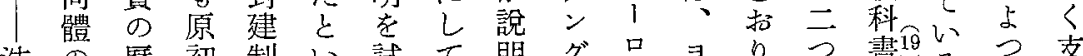

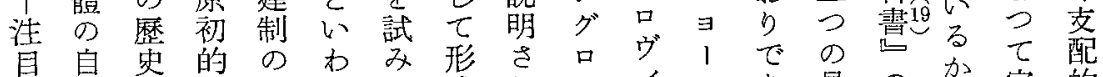

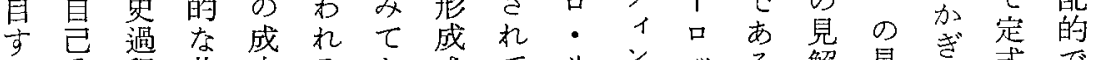

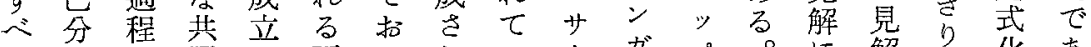

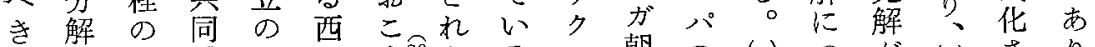

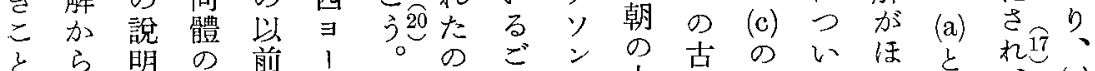

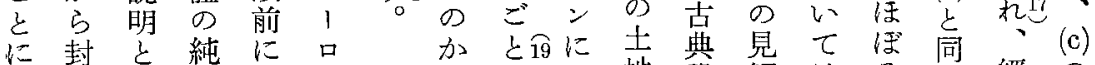

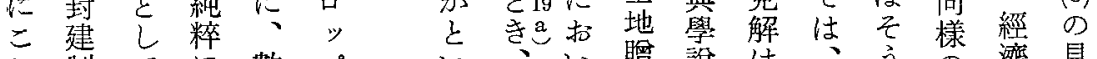
机制てに數パ い、贈說は、、方の濟見

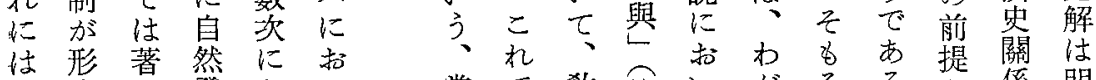

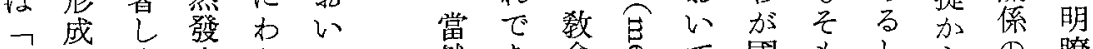

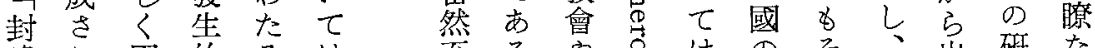

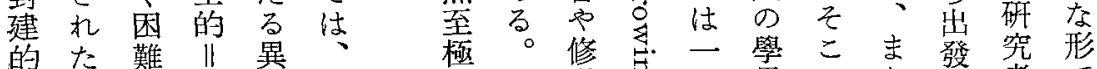

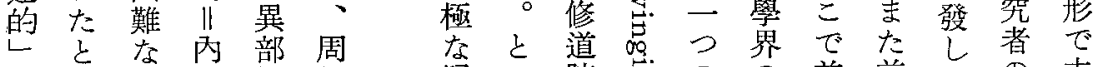

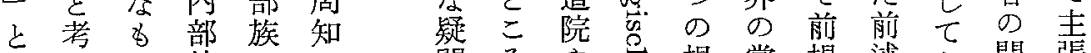

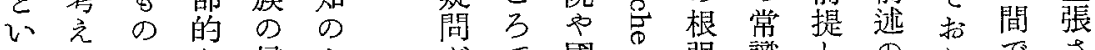
うるにな侵よで國た强識と市りりでさ

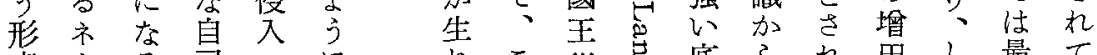

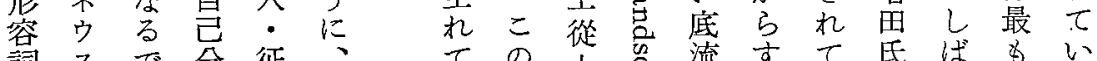
詞 スで分征、て の 士号流古て 氏

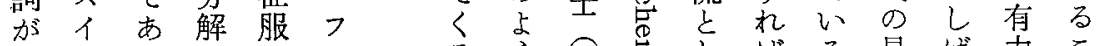

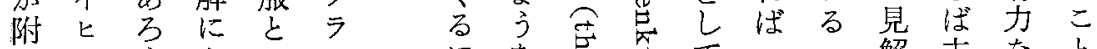

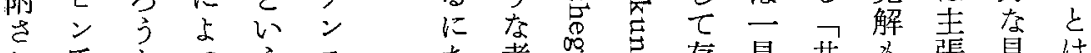

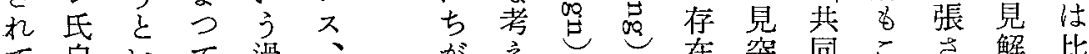
て自心て過、加方 心身う、程ドい方ににし飛體れれれと較 ながこ封がイに對よてな后なな的

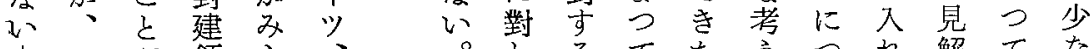




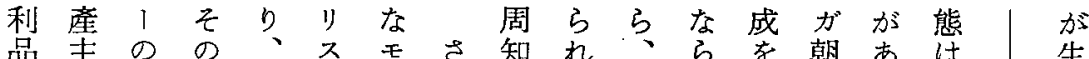

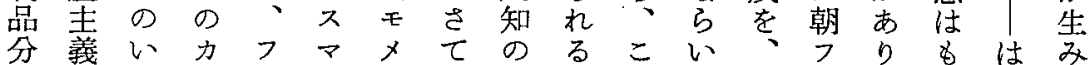
配的 わ リ

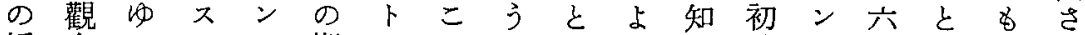

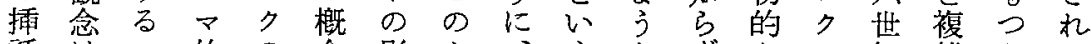

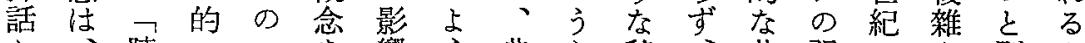
か、陣二つを響う典と移、共强にな別た

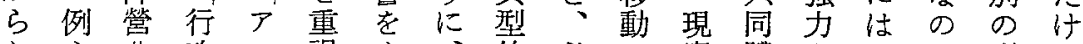
し之 II 政ン 視す、的必・鿓體なメ无形で

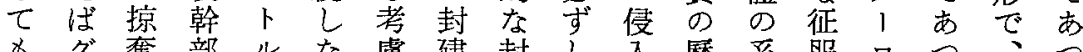

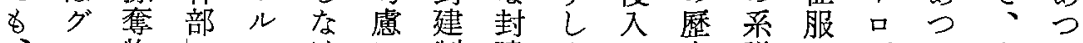
推 ゴ共で

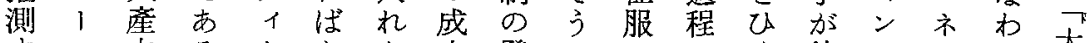
すル圭るオなな 立發での伸がウく奇

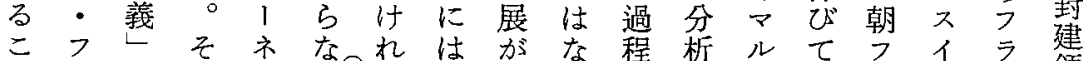

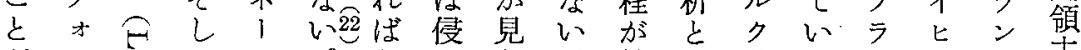

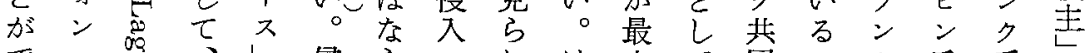

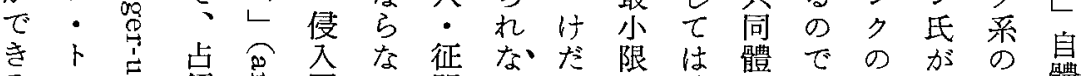
る

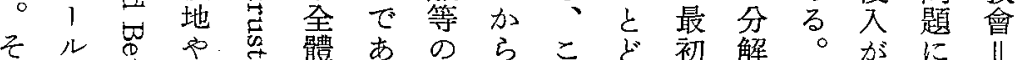
れの

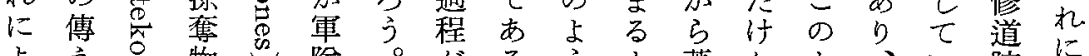

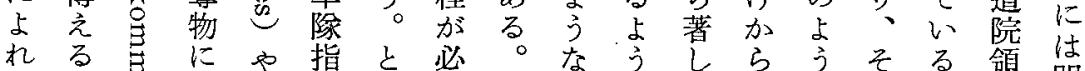

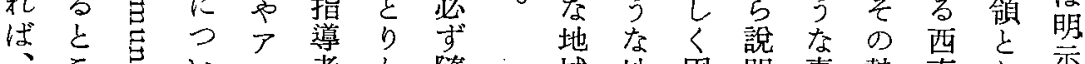
、气点Wン者わ隨、域地困明事勢南し示 ク ヴクが二 サ カ

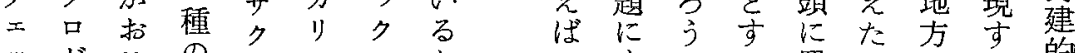

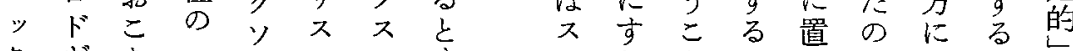

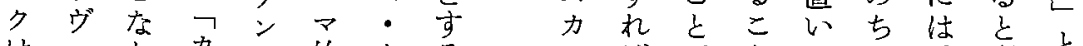

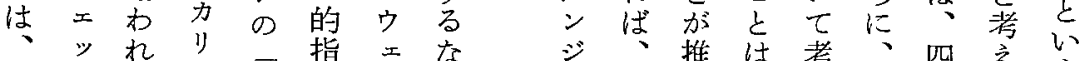

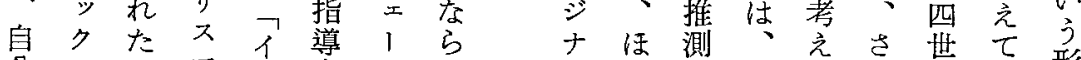

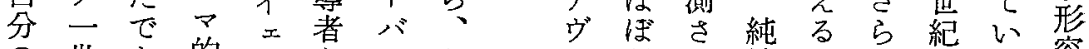

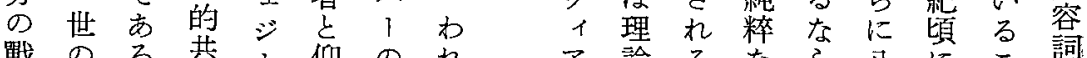
戰の る 共 1 仰 の れ 利莗引。産

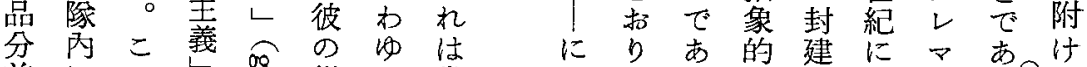

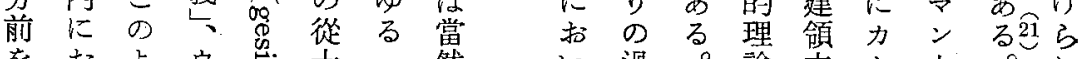

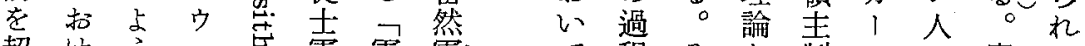

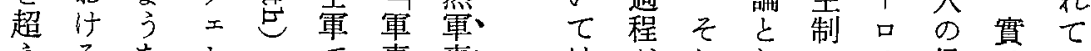

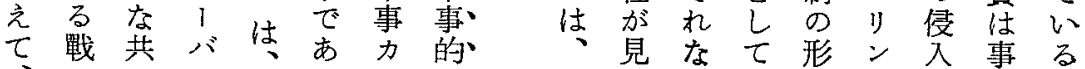




\section{封建社會をめぐる諸問題}

まな投い方なスにみ全和は考同る達さ

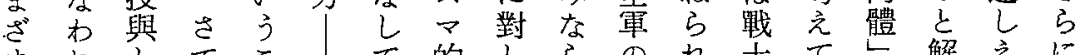

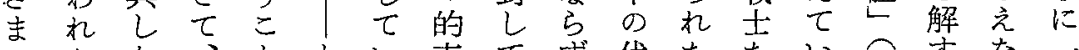

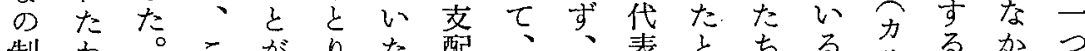

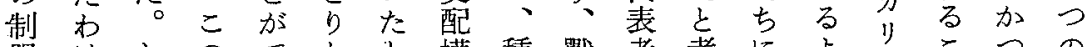
限けしのでかと權種戰者考によ゙こつの

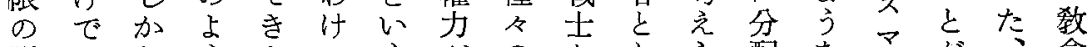
附あしうる

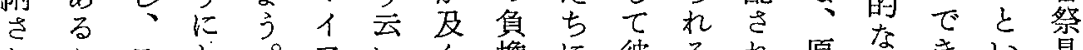
机加こし。アいん擔に彼る。机原な゙きい具 た 所

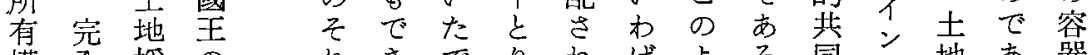
權全授の れきでり机ばよう同ジ地あ 器

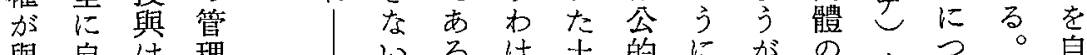

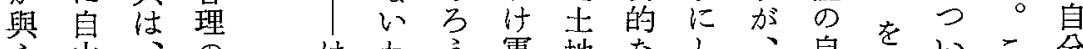

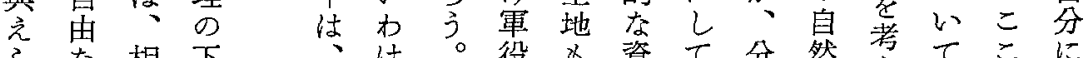
らな相下、け。役当資て 分然考七こに

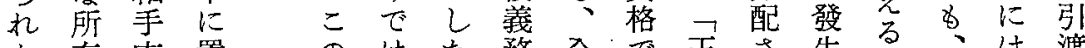

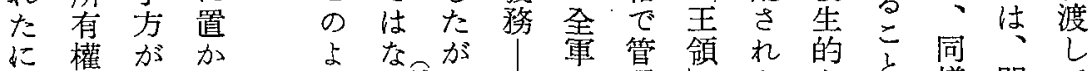
む權 怔加

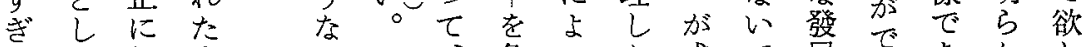
なて 行土

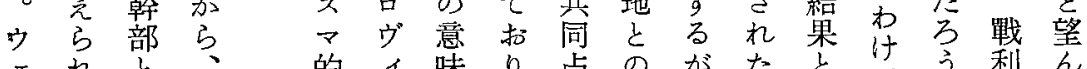

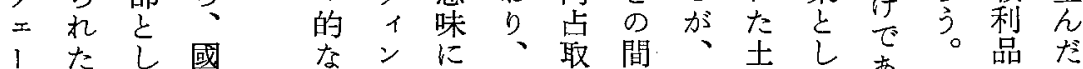

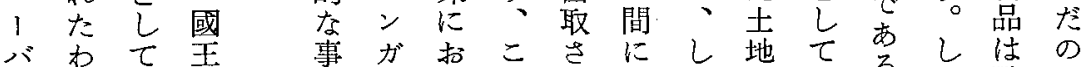

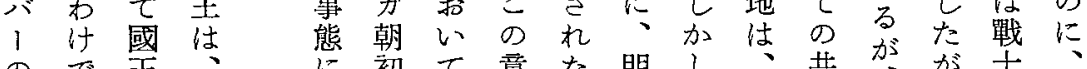
のて主、初て意た明し、共㤎が士 用はにて 期は昧士確、全同しつた軍 語な勤のに、で地な或軍體加て、ち像 をく務行てつあ、はで區主豚で加い全中 用、し政のいら、文別ののは員の いいて幹誤てゆああるが私指なをこのた るわい部つのるらがつ經導い。扎に方た

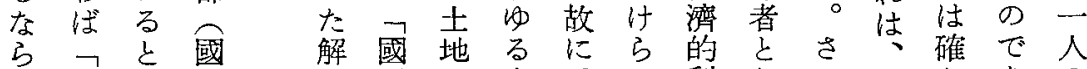

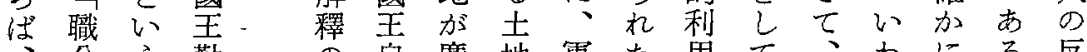
分う勤 の自廣地軍た用ている反

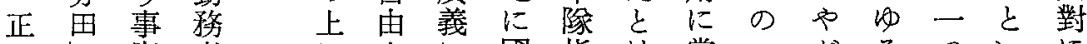
によ實者に人に國指は當公がるついに

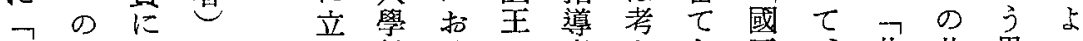
プごるに つ說けの者えら王、共共思つ

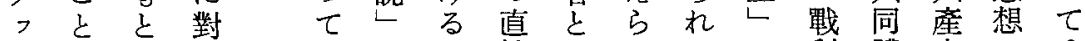

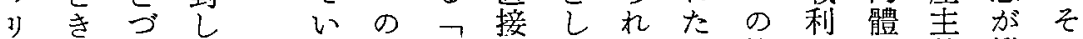
二形いて る說王的てな管品理義働の ンでて士 明領なのい地理や論的い希

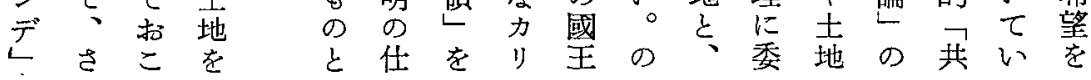




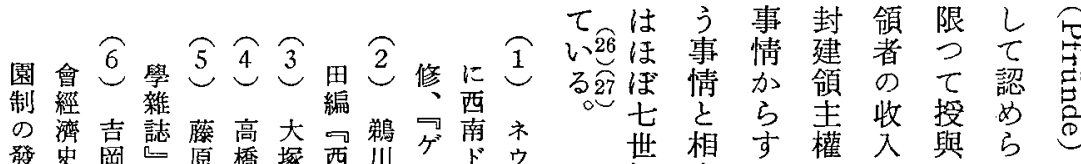

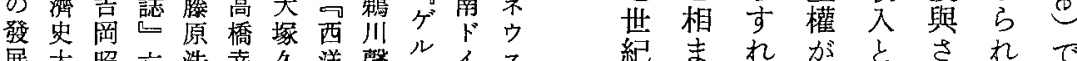

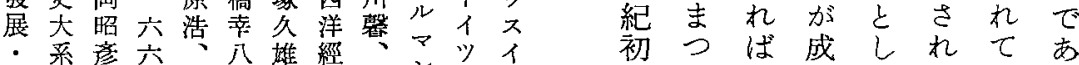

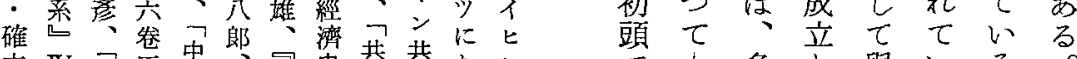

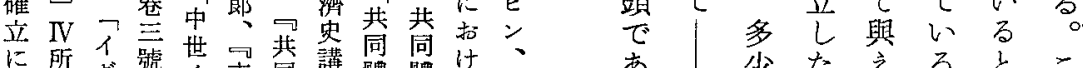
に所ギ號世圭同講體體る福市、少だるるとこ 件政 1

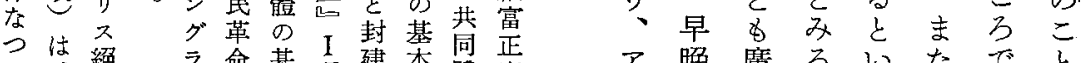

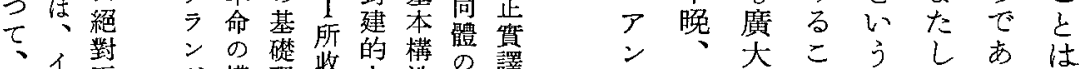

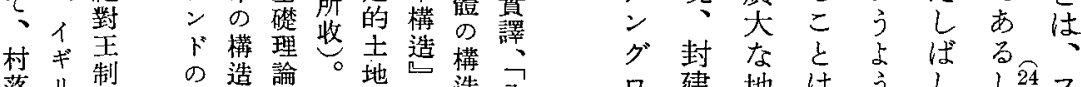

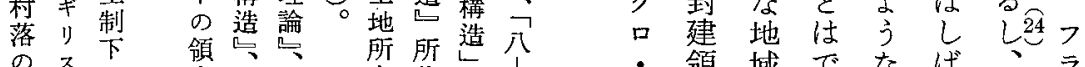

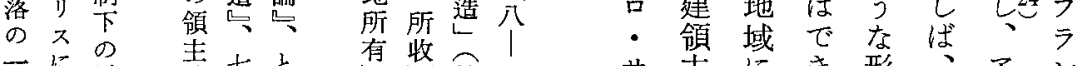

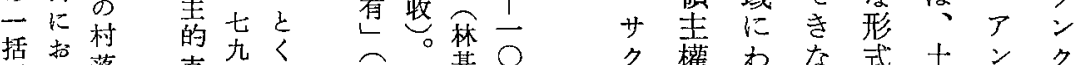
所以落支真に文基

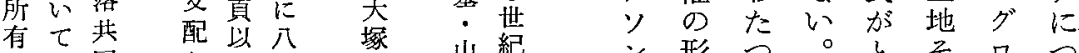

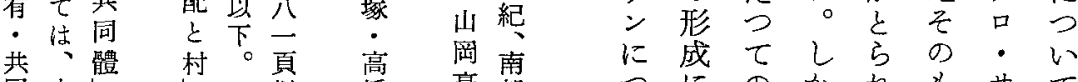

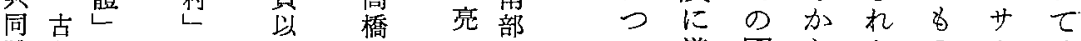

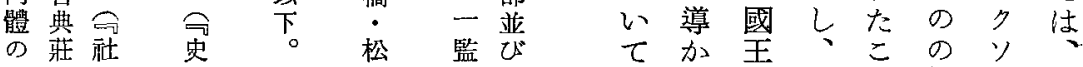

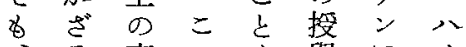
る 直の严與にイ

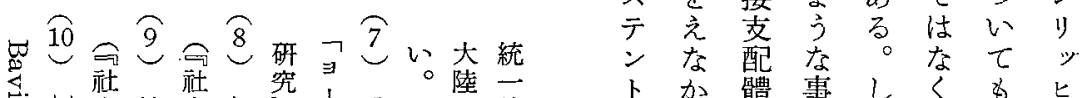

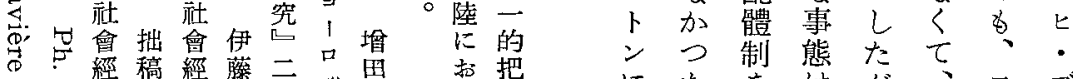

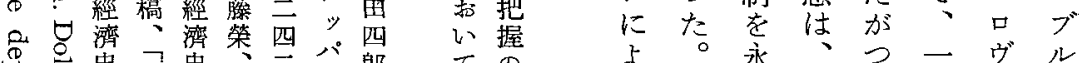

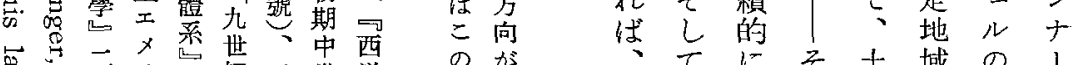
巾

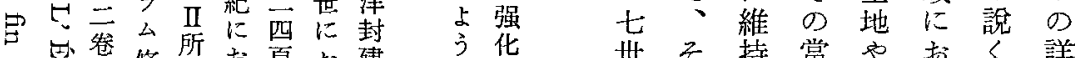

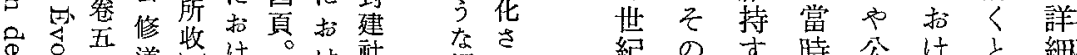

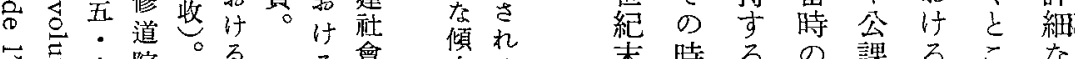
灾売六院。るる會向る 束時るの課るこな 总號の 志焉三儿

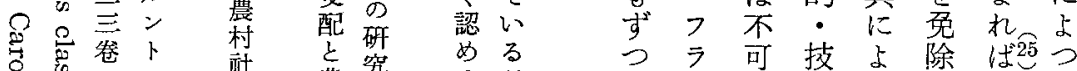

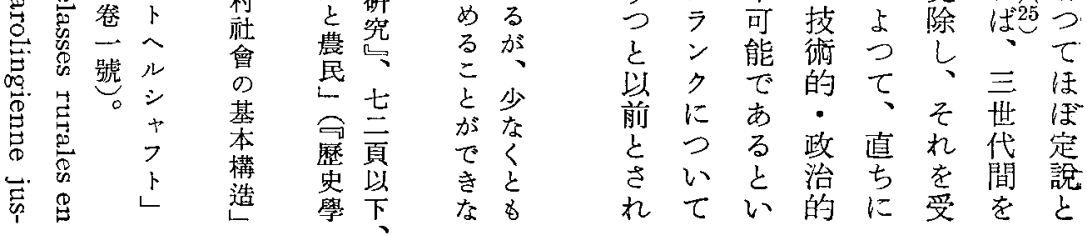




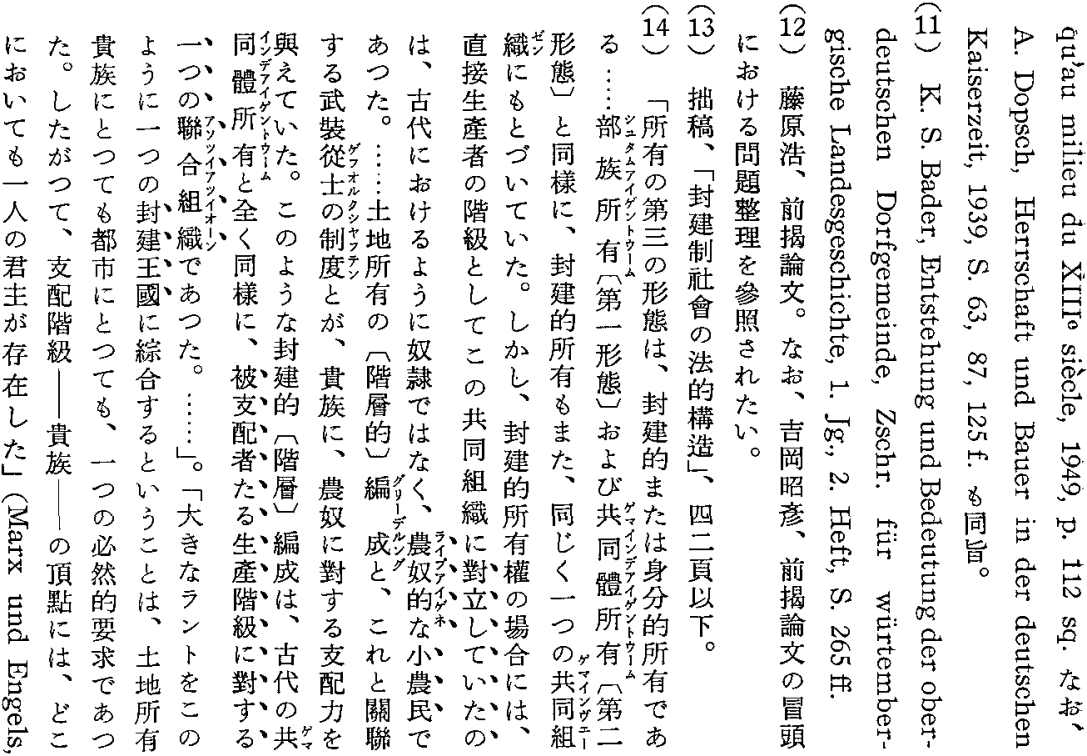

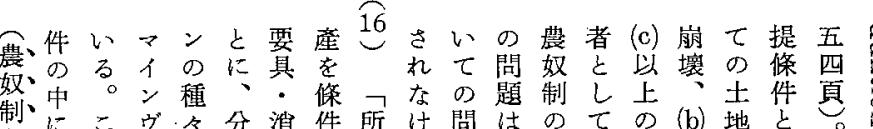

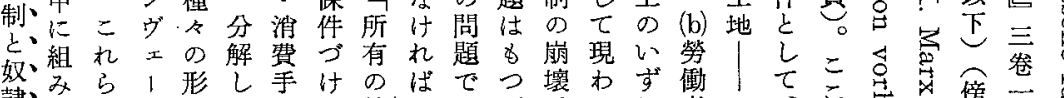

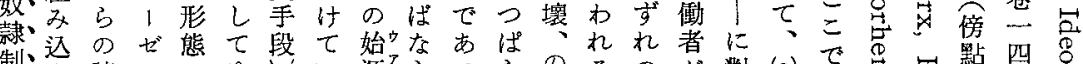

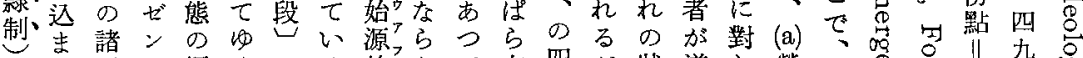

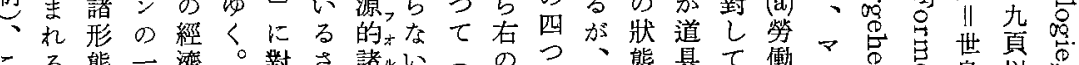

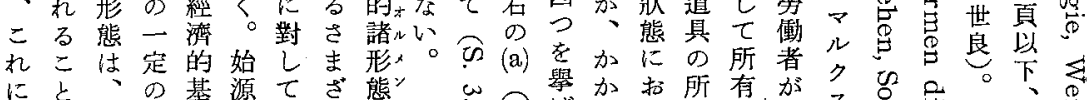

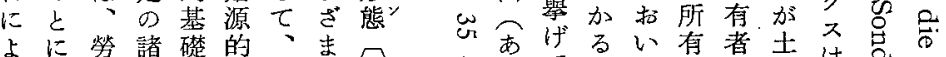

よに勞諸礎的自学前 て 自態な形白客註 てて體を古態 の觀 の

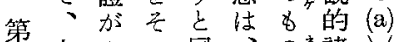
一本、客の同、の*諎

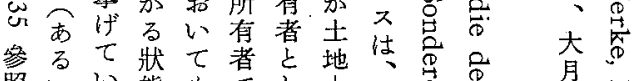

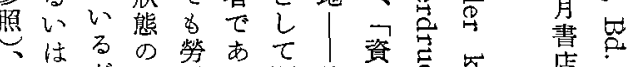

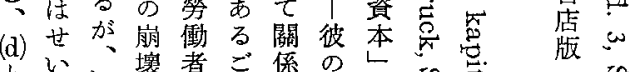
質、觀 前時 ゲと 契 は

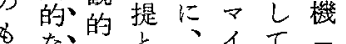
をな的々、イて必 の變ななそ之閣土然 更生七机占係地的

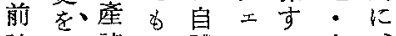
註う諸つ體 1 る生、 のけ條てゲゼこ産生

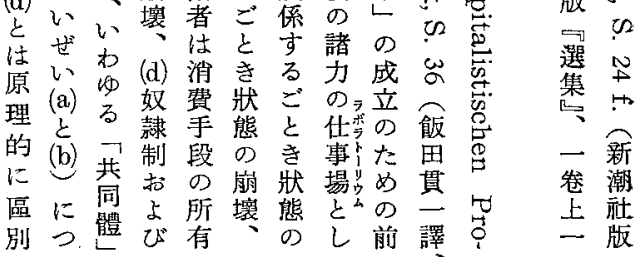


らわンに意 ア 犯良て生

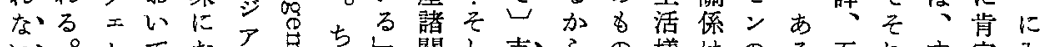

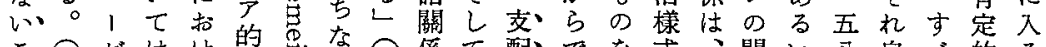

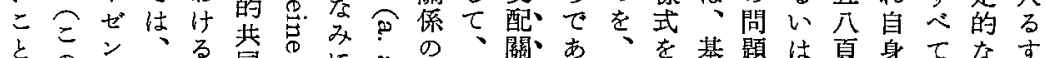

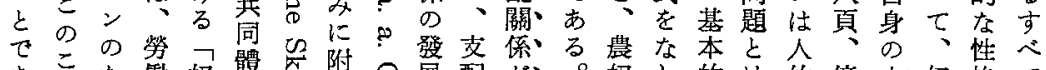
あこた働奴體芯附○展配肪。奴し的は的傍止奴格七

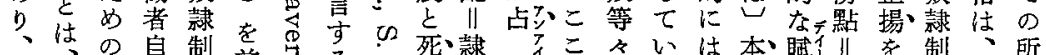

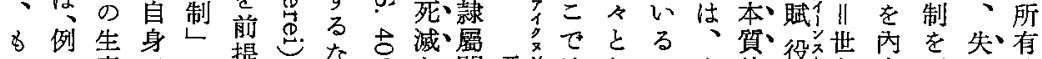

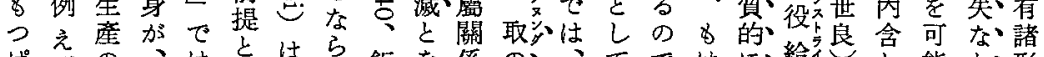

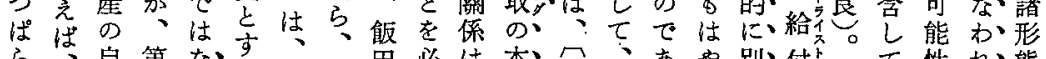

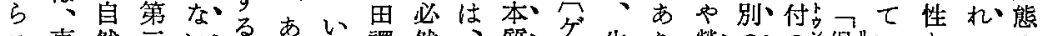

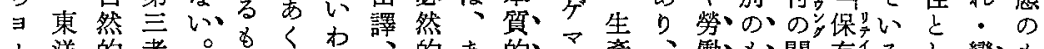

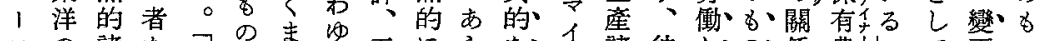

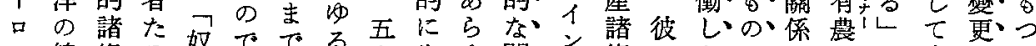

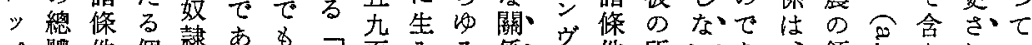

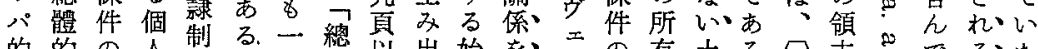

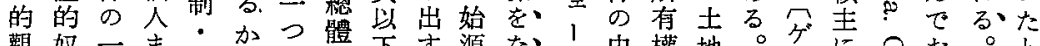

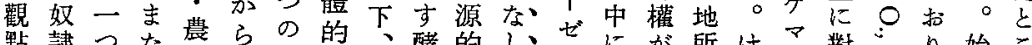

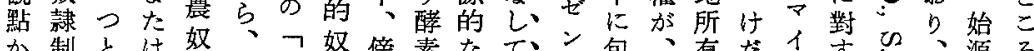
らにしゲ制本䆚隷點を所いで含勞者しンる゙しし的の

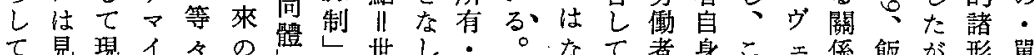

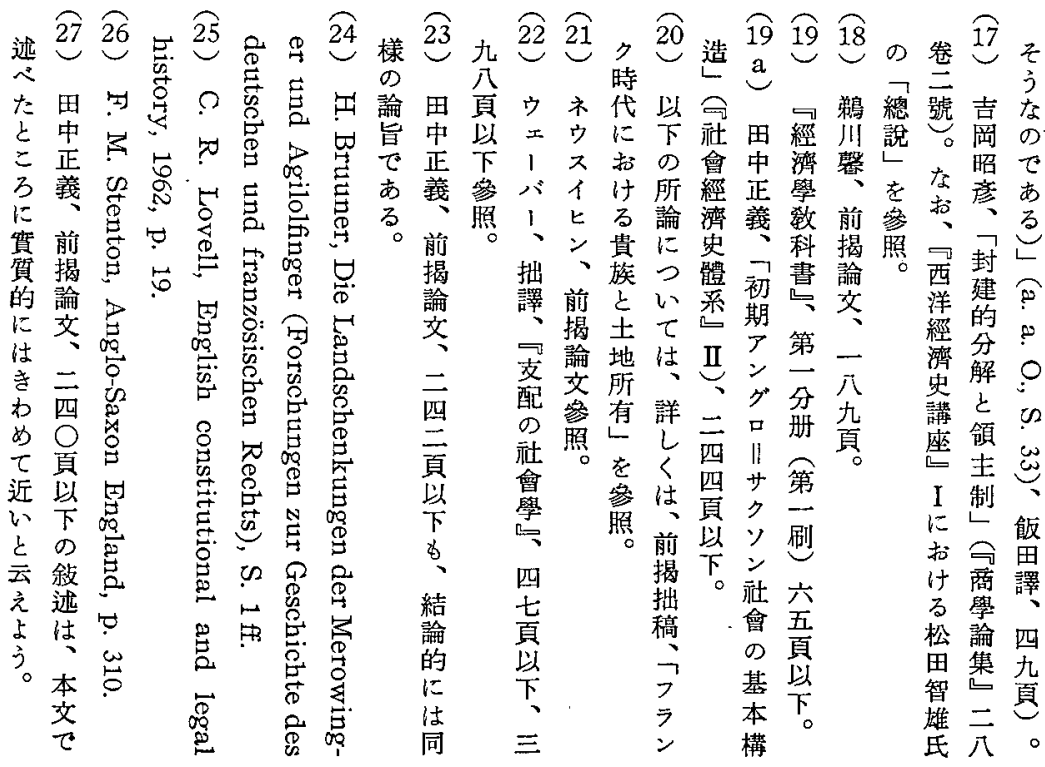




\section{封建社會をめぐる諸問題}

裁ある。市るの地念岩承批に牛

制る肪さとるの封所に波認制值ほ最

領がこてここは建有對の文はいに゙後

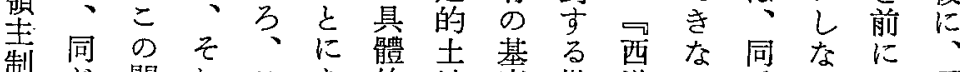

制し問れこあ的地底批洋い氏心代

人く題での

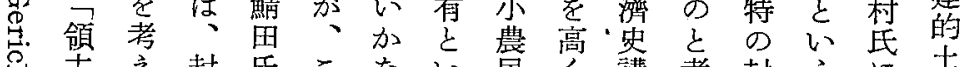

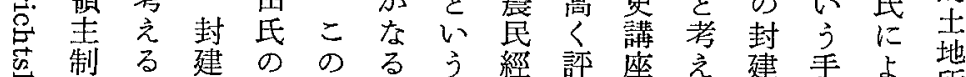

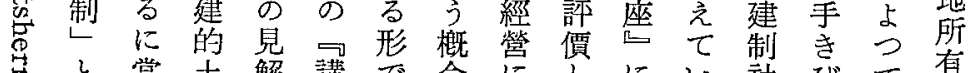

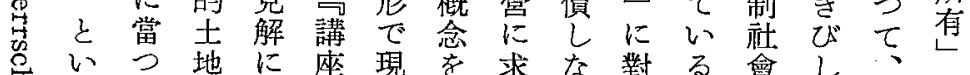

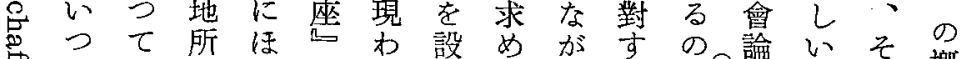

导ては有ばはれ䇥たらるでを批れ概

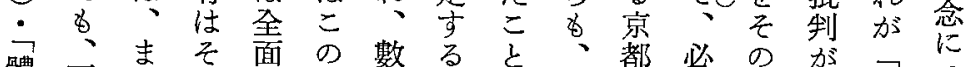

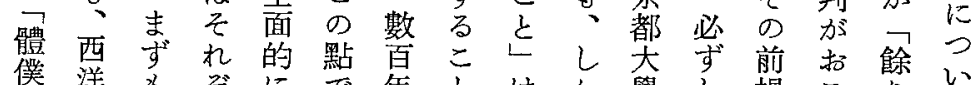

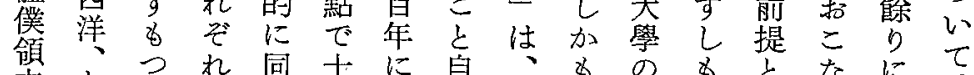

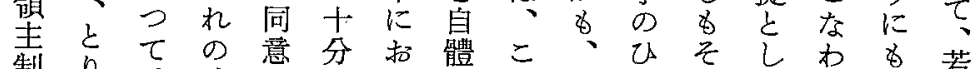

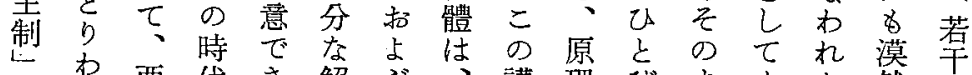

ま け西代き解ふ心講理びますた 然古

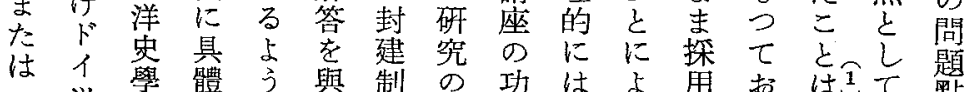

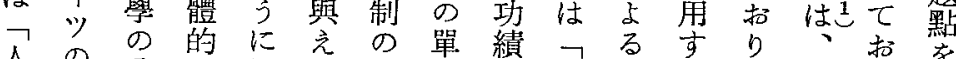

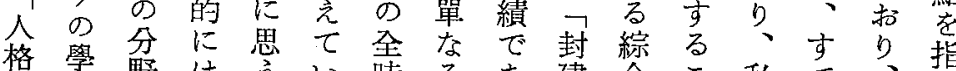

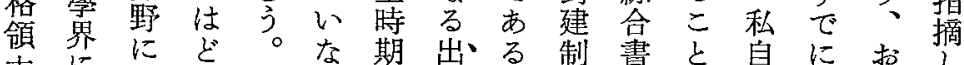

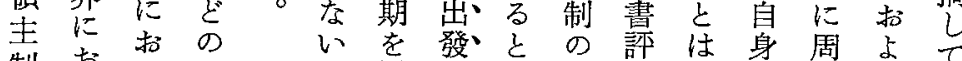

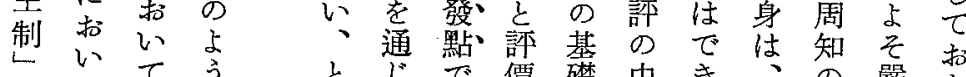

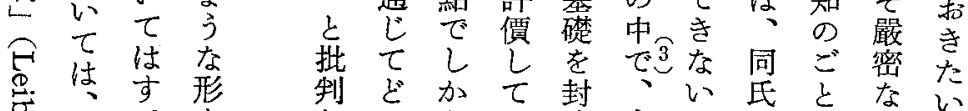

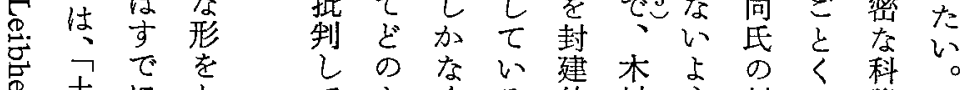

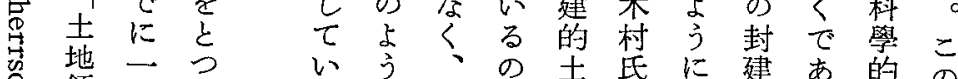

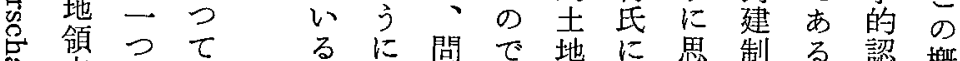

怘琵の

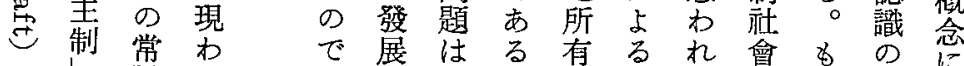

と識れ市し、。につる論つ手に

いる人るてて封た打封。はと段い

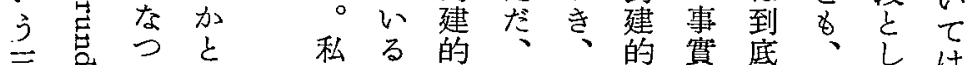

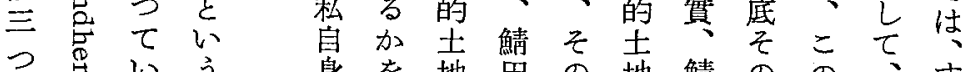

の 要いう身を地界の地鯖の市、す

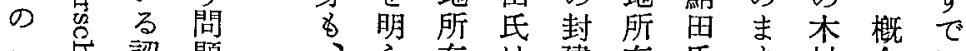

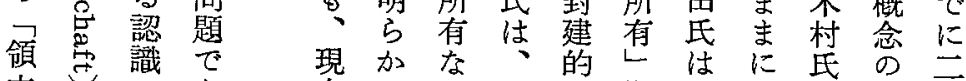

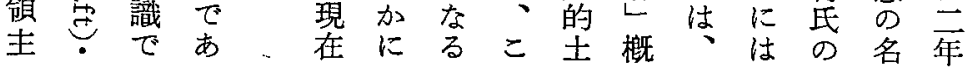




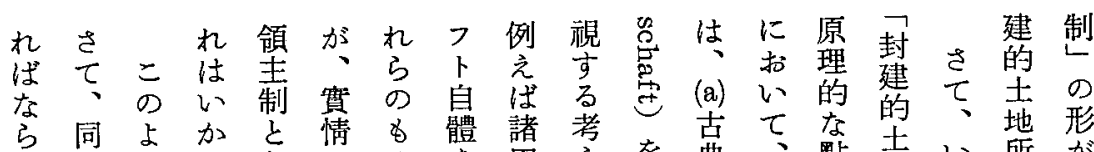
な 氐 う な

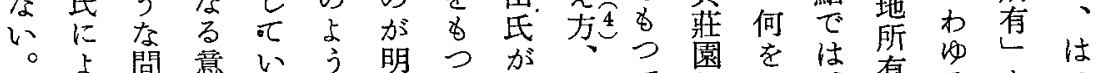
すれ邀沬うに確て なばにでま思に封ンつ體つわわのつのき わ、對村 でか 區 建 $゙$ 裁封後てがの古關り

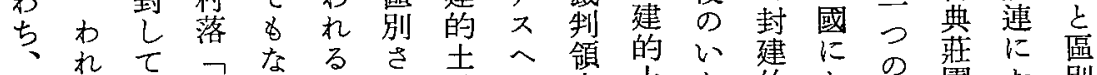

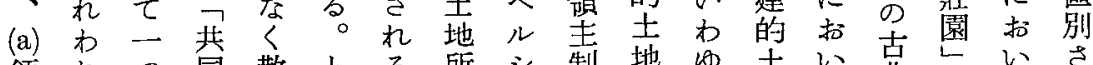
領机つ 䆚 散 こ る 對 拓理 ᄂ 的 $と$ で と有

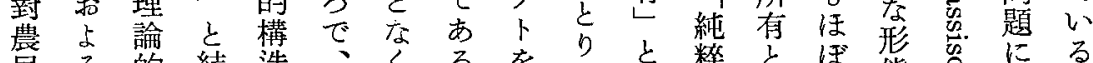

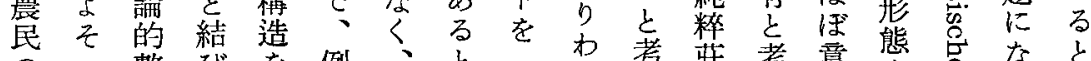

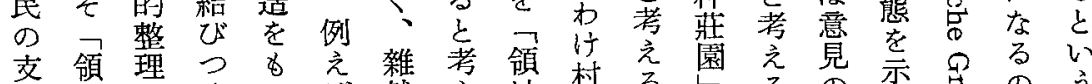

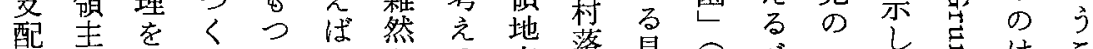

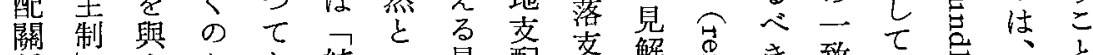

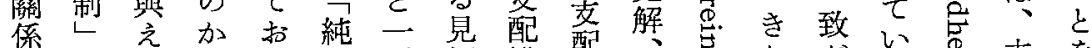

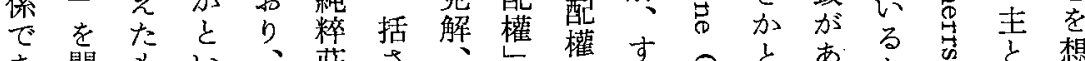

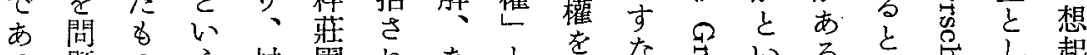

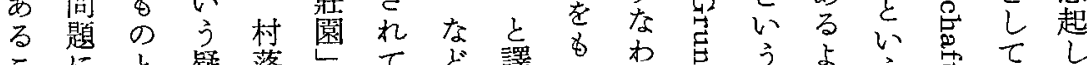
(b) 方 そた私生るてになる來の的段るすわ地必

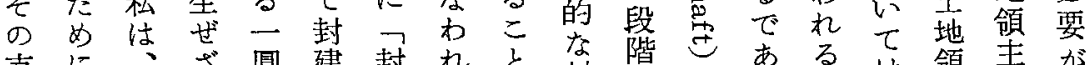

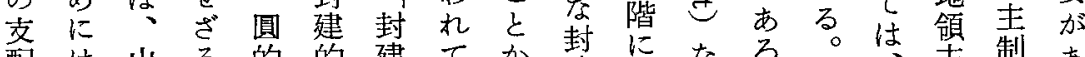

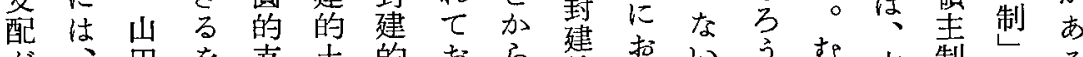

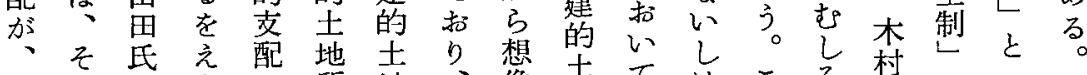

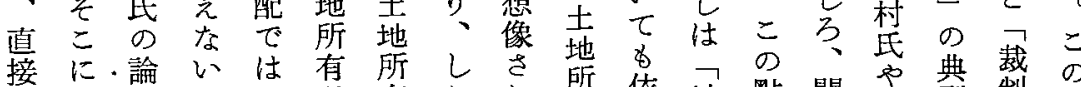

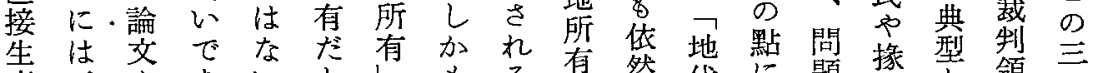
產三を あ

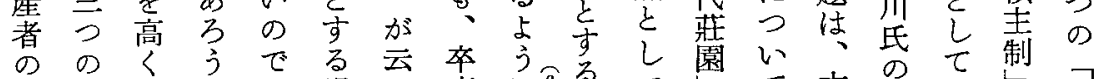

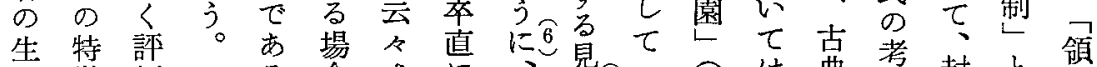

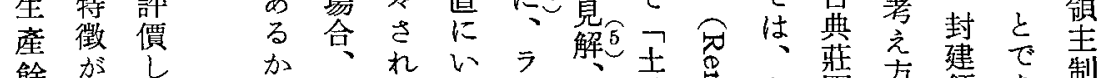

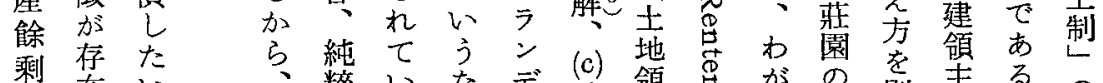
體し 考 直 裝 る

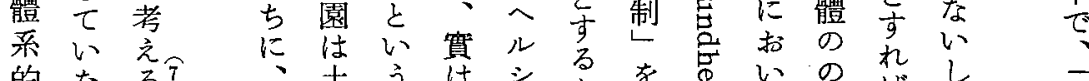

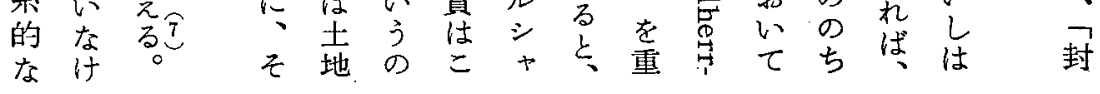




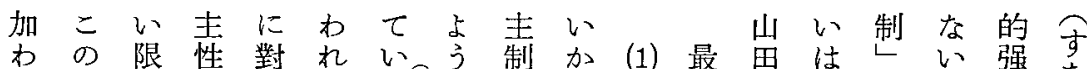

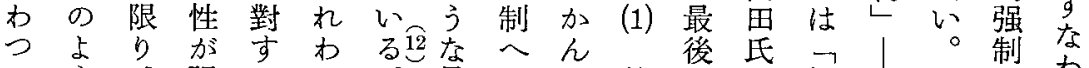

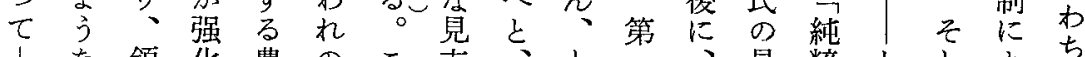

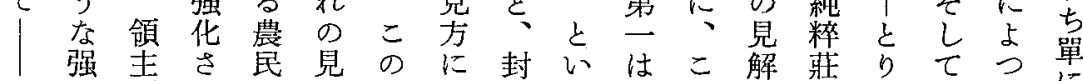

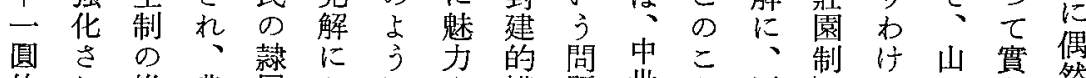

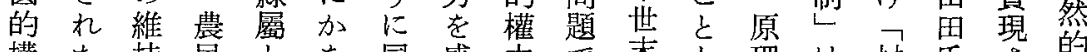
構た持民とな同感力で湘と理は村氏さ的 造檴はが心り氏无のあ期關的落は机で を力困容う接のついる。連に語㕝はては

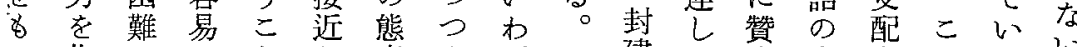
つ作ににとし度它ばこ建て成本者のるし

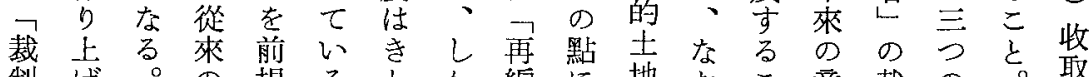
制将。の提る加編に地扰こ意裁の取

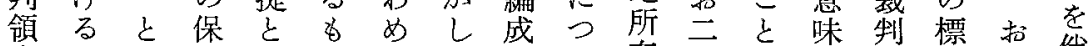

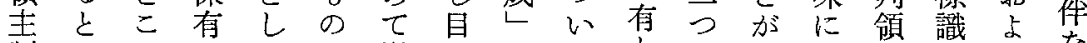

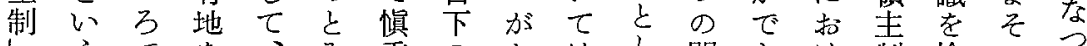

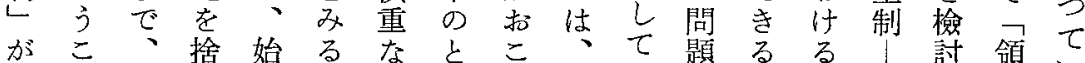
登と土㫟始る る

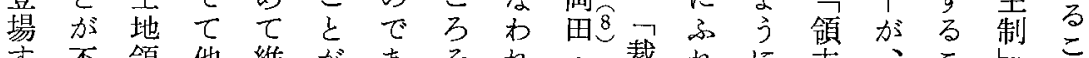

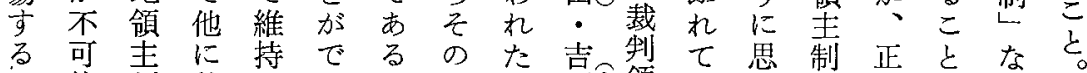
こ 能制 移さ き にあるうううしない瀨制たな領つす生

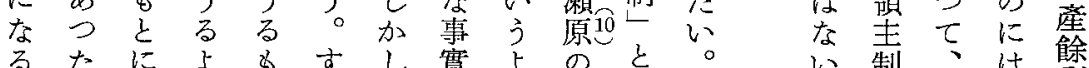

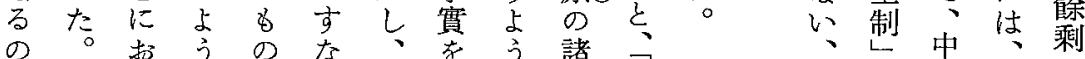

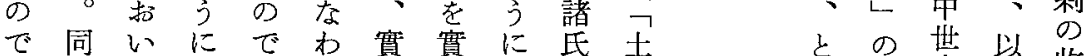
あ氏てなあち質證考多地 る13にはるり、的市光、領 ○よ、文同にるたま主 これそくし氏はこかた制 のば机よたに、とけ私し よ、にり斿よ次がで自と

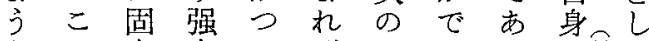
なこ有力て代占きるす 說になな、方ななが、の 明、分領土土にい、古 に|散主地地說と山典古 即|所權に領くし田莊 典 し 他 領 力 對慰こて氏 園 莊 て の 構 がす 制と、自制 園 考モ造形る貍に斷身加电 えメに成農はよ定はらを るンよさ民良つる、裁の 限卜つれ り。京な自地、光の領係 名禁紧收 化期 尗取 結 值の 方 論出 オ にす、品農 到る ス 標 の 達的占識隷 し 心あに悀性 るり 技揱 私土て提 自地はな所な 有裁れる 、權制ば經 こ市領な濟 
こだ、゙ れと 载う圭 地 か 法建 點 論主 あ こ

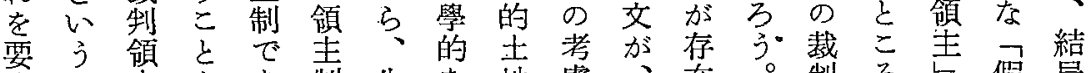

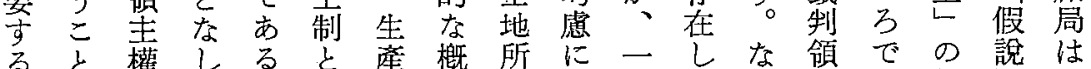
ると權しにる

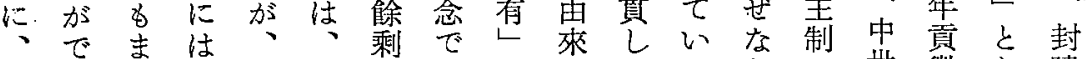

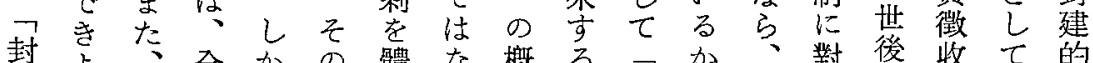

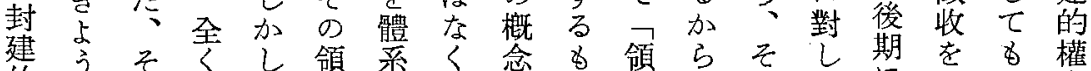

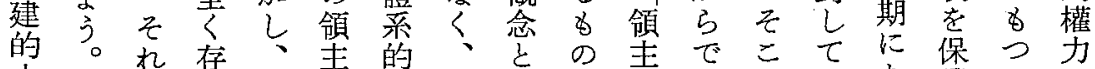
土标音政孝的、支の主でこてに保つ力

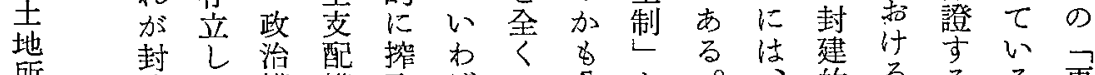

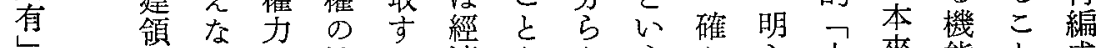

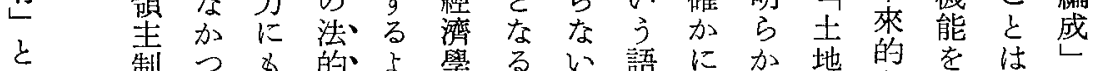
い 制つ る 的よ 學る る 概市こ方㹉なな角ここ有領つ方し 概るとくは機いるかか心封し声た がて

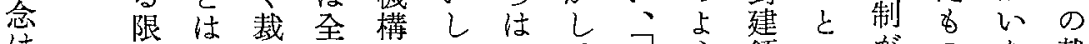

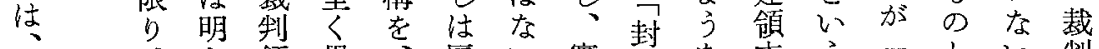

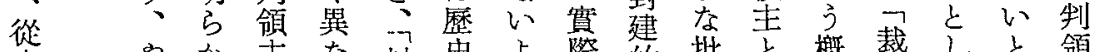
來や加主な封史与際的批之概裁と領 か はで制つ建 學う の 土刵し念制て み主 なりあとて 的的に問地にて 志領現て 制 り 一る心打士な思題所はの用圭わよの あ種。えり地概 す方有考裁心制れ加成

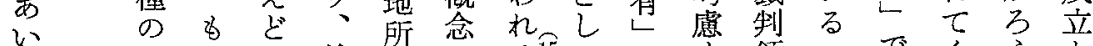

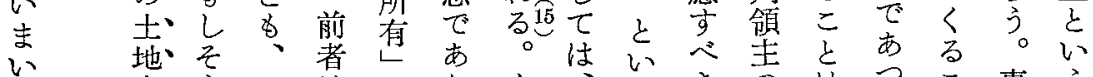

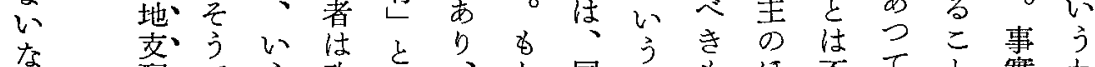

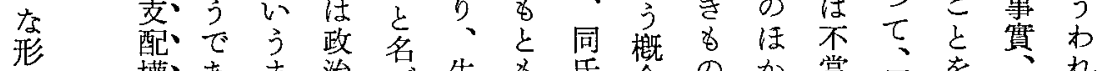

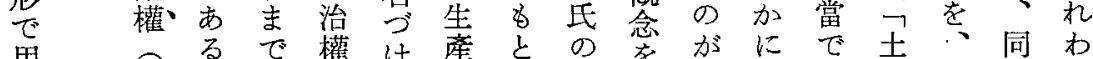

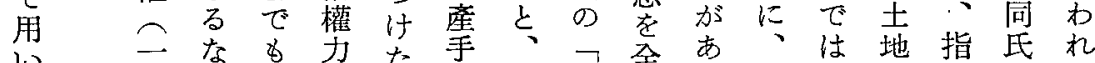

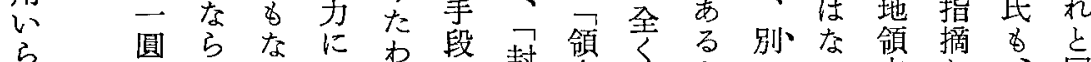

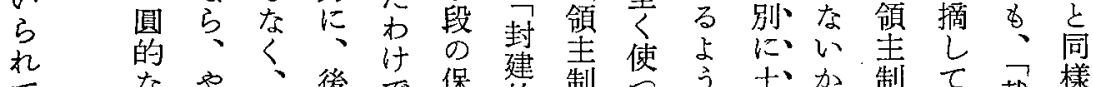

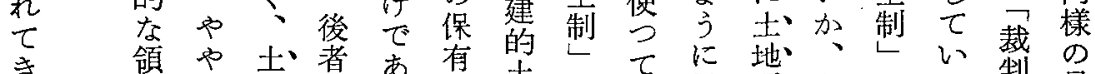
さ 領 逆 地、者あ 有 土 、支說 生土去で地概なお有いはの領解

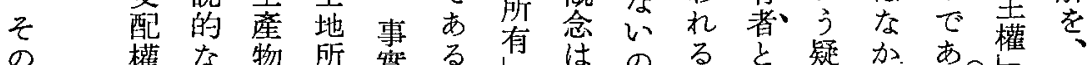

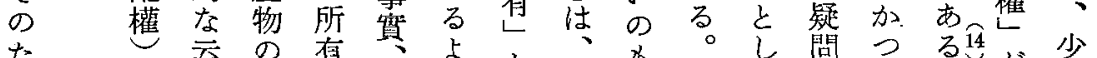

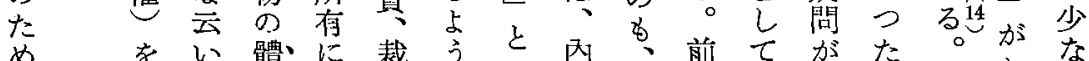
めを い體に藏 う に 含 方 系基 制 な えであ㩈を主接概にい山粹てるる ついる取置制生念は注莊くと最 


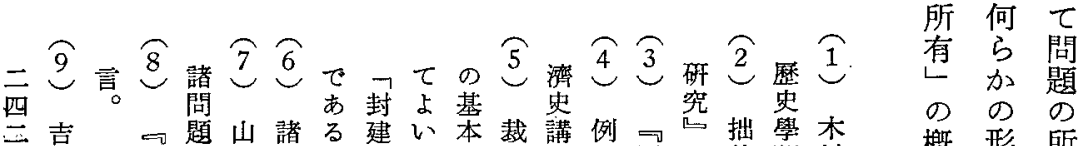

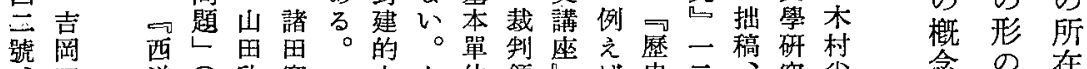

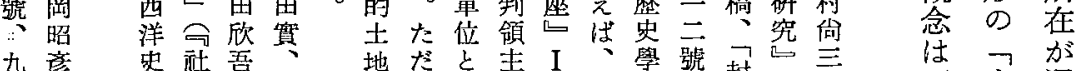

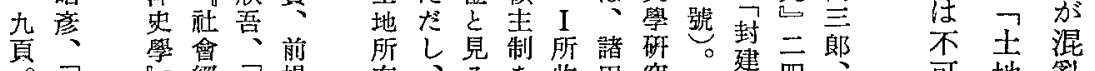

封巨經中揭有、吉学收思究制四、可地销

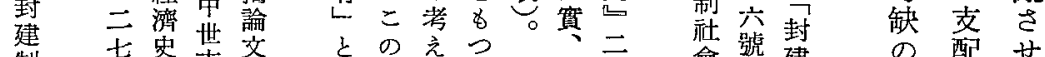

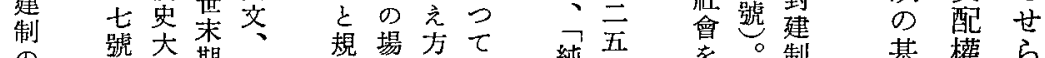

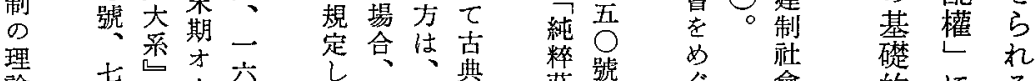

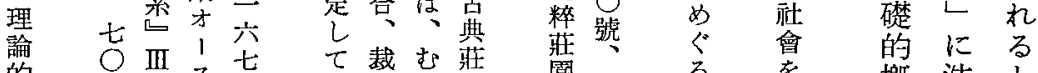

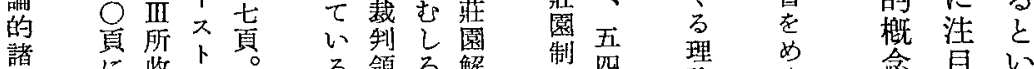

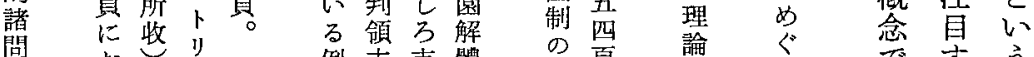

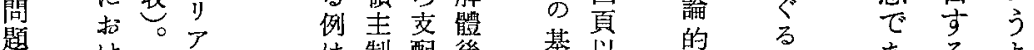

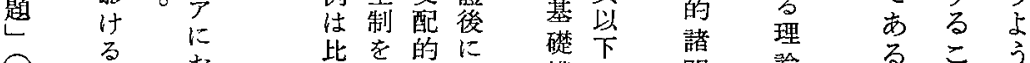

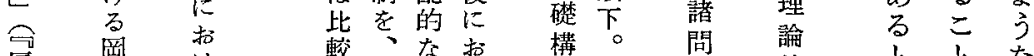

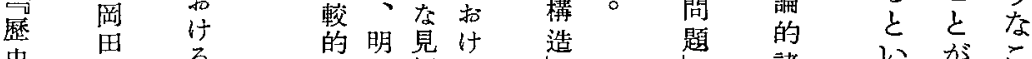

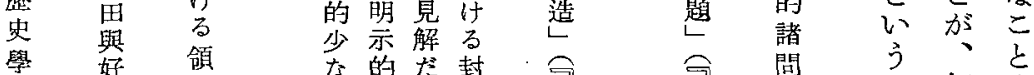

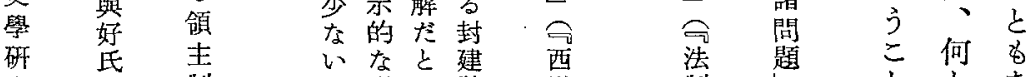

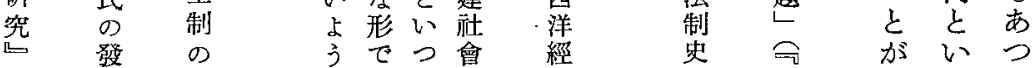

でつた

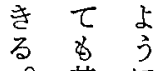

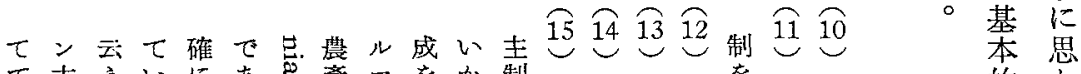

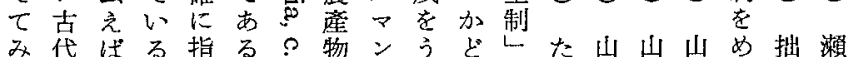

てかこ加摘と心を古るう概た思思田ぐ稿原

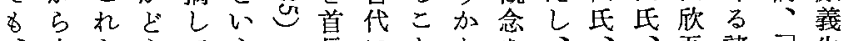

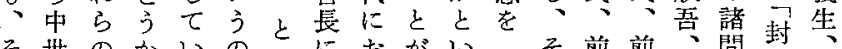

そ世のかいのいにおがいて前前、問建

れ諸さるでうるけてう封の揭揭前題建西

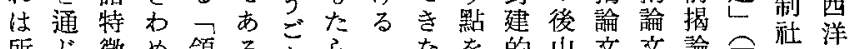

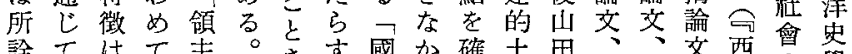

詮てはて圭。きす國加確土田、交西兽學

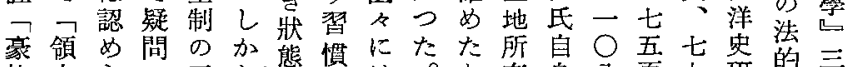

族主らで三し.態怔は。之有身八頁九研的三

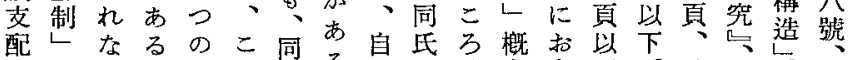

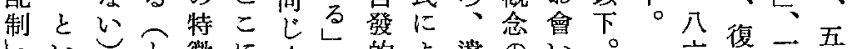

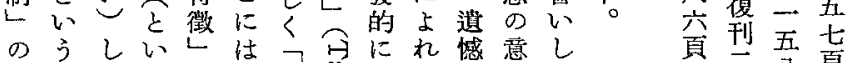

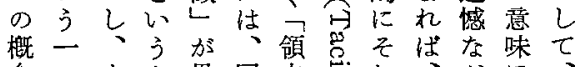

念つまを果同圭悹机、例ら理同

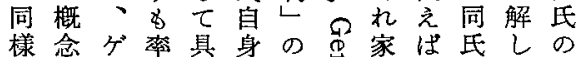

貝侌公真

的 t

に机

重 る

要 加

操 し

作 加

だ し

b 封

乙建

の會

意の

味 分

で 析

$\neg に$

封 2

建つ

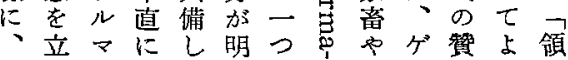

七㫔

的

貝 封

土他 
々き

jめ

疑

問

尼

禁容

にな

之 है

なの

wに

- な

ᄂ 5

たざ

がる

つを

てな

私い

見の

にで

上 仕

れな

喿い

同

同

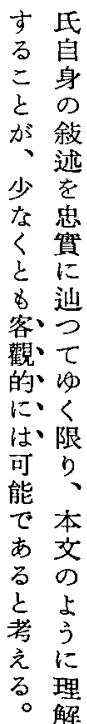

160 


\title{
Hauptströmungen in der Auffassung des europäischen Feudalismus in Japan
}

\author{
von Terushirō Sera
}

Nach dem letzten Weltkrieg sind in Japan Zwei neue Theorien betreffend der Auffassung der europäischen feudalen Gesellschaft aufgetaucht. Nämlich :

1) die ,Königsfreientheorie", die in Deutschland in den vierziger Jahren dieses Jahrhunderts von Th. Mayer und $H$. Dannenbaur aufgestellt war und dort seither mehr und mehr eine herrschende Stellung eingenommen hat. Auch in Japan hat sie bei einigen Erforschern der deutschen Geschichte eine große Beistimmung gefunden.

2) die marxistische "Gemeindetheorie", welche, beruhend auf einem Aufsatz von Karl Marx (,Formen, die der kapitalistischen Produktion vorhergehen "), die Behauptung aufstellt, daß einer feudalen Gesellschaft stets eine feudale (Dorf-) Gemeinde zugrunde liegen müsste. Diese Theorie bildet in unserem Land, wenigstens unter den Wirtschatsgeschichtlern, eine fast herrschende Ansicht.

Neben diesen zwei neuen Theorien hat natürlich die orthodoxe , klassische Theorie" wie sie in England und Frankreich noch jetzt ganz herrschend ist, auch in unserem Land viele Anhänger.

Diese drei Theorien stehen nun, zu meinem grossen Bedauern, gegeneinander fast ganz gleichgütig nebeneinander, ohne sich auseinandersetzen zu wollen. Solch ein blosses Nebeneinander ist natürlish nicht zur wünschen und muss überwunden werden. Eine lebhafte Polemik untereinander ist dringend nötig. Dabei bilden die folgende punkte wohl die wichtigsten Streitpunkte.

1) Die ,klassische Theorie" kann nicht mehr in unveränderter Gestalt erhalten werden. Besonders sind die Markgenossenschaftstheorie, der freibäuerliche Hufenbegriff und der Begriff der , Gemeinfreien “ erneunt nachzuprüfen.

2) Auch die "Königsfreientheorie" kann, meiner Erachtung nach, in solcher Gestalt, wie sie in Deutschland verfochten ist, nicht anerkannt 
werden. Namentlich sind die folgenden Punkte zu beachten.

a) Der Begriff des ,Königsfreien “ ist ganz unbestimmt gebraucht. Der Bestimmung nach muss ein Königsfreier eine sich im Verhältnis zum König in einer Hörigkeitsstellung befindliche Person sein, die auf dem Königsland angesiedelt und deren Freiheit vom König verliehen ist. Also wenigstens drei Momente: Hörigkeit (freie Unfreiheit), Königslandsiedlung und verliehene Freiheit sind wesentlich in der Bestimmung des Begriffs. Trotzdem in der tatsächlichen Behandlung des Problems folgert man oft auf das Vorhandensein eines Königsfreien ziemlich willkürlich, wenn nur eines jener drei Momente bewiesen werden kann.

b) Der Begriff des Königsfreien ist ein solcher, der vorläufig nur ein Programm des Königs zum Ausdruck bringt. Wir können nicht aus den Bestimmungen der Kapitularien ohne weiteres annehmen, daß es auch in der Wirklichkeit einen einheitlichen Stand der königsfreien gäbe. Die Verfechter dieser Theorie verwechseln aber oft Programm und Wirklichkeit. Wir haben daher genug Grund, erneut zu fragen, wieviele Tragweite denn der Begriff des Königsfreien habe in der Erforschung der wirklichen Geschichtsentwicklung im früheren Mittelalter.

3) Betreffend der marxistischen , Gemeindetheorie " sind vornehmlich die folgenden Punkte hervorzuheben.

a) Die konkrete Gestalt der Dorfgemeinde vor dem 13. Jahrhundert ist noch nicht genug klar gemacht. Insbesondere ist ein entscheidendes Problem: das Verhältnis zwischen der geschlossenen Dorfgemeinde und dem Streubesitz der Grundherrschaft noch gar nicht geklärt.

b) Nach dieser Theorie ist die Schicht der Feudalherren aus der Auflösung der einheitlichen freibäuerlichen Schicht, die einst die Genossen der Dorfgemeinde gebildet hätten, in einem sozusagen natürlichen Prozess entstanden. Aber vor dem Entstehen des Feudalismus kann überall ein Prozess der Wandlung, Eroberung und Einverleibung der Völker beobachtet werden, und dieser Vorgang musste einen entscheidenden Einfluss auf die soziale Gliederung haben. Wir können daher den wirklichen Vorgang der Geschichte nicht genug erklären, ohne diesen Prozess der Wandlung und Eroberung in Betracht zu nehmen.

c) Auch der Begriff des ,feudallen Grundeigentums " ist nicht eindeutig bestimmt. Die Frage, ob wir die Grunđherrschaft oder die Gerichtsherrs- 
chaft oder beide als ein solches zu erfassen haben, und ob die sog. reine Grundherrschaft auch als ein fetdales Grundeigentum zu betrachten ist, noch nicht klar beantwortet.

d) Eine in Japan einflussreiche Meinung versteht unter der ,germanischen Form " der Gemeinde von K. Marx eine feudale Gemeinde. Dies ist aber offensichtlich Missdeutung. Marx selbst behandelt ja in seiner „, Deutsche Ideologie" (Marx-Engels Werke, III, S. 24f.) die Lehenspyramide als ein feudales Gemeinwesen. 